Chapter 8

\title{
The Important Role of Packaging in Operations Management
}

\author{
Alberto Regattieri and Giulia Santarelli \\ Additional information is available at the end of the chapter \\ http://dx.doi.org/10.5772/54073
}

\section{Introduction}

The chapter focuses on the analysis of the impact of packaging in Operations Management $(\mathrm{OM})$ along the whole supply chain. The product packaging system (i.e. primary, secondary and tertiary packages and accessories) is highly relevant in the supply chain and its importance is growing because of the necessity to minimize costs, reduce the environmental impact and also due to the development of web operations (i.e. electronic commerce).

A typical supply chain is an end-to-end process with the main purpose of production, transportation, and distribution of products. It is relative to the products' movements normally from the supplier to the manufacturer, distributor, retailer and finally the end consumer. All products moved are contained in packages and for this reason the analysis of the physical logistics flows and the role of packaging is a very important issue for the definition and design of manufacturing processes, improvement of layout and increase in companies' efficiency.

In recent years, companies have started to consider packaging as a critical issue. It is necessary to analyse the packages' characteristics (e.g. shape, materials, transport, etc.) in order to improve the performance of companies and minimize their costs. Packaging concerns all activities of a company: from the purchasing of raw materials to the production and sale of finished products, and during transport and distribution.

In order to manage the activities directly linked with the manufacturing of products (and consequently with the packaging system), the OM discipline is defined. It is responsible for collecting various inputs and converting them into desired outputs through operations [1].

Recently, more and more companies have started to use web operations. Electronic commerce (e-commerce) is the most promising application of information technology witnessed 
in recent years. It is revolutionising supply chain management and has enormous potential for manufacturing, retail and service operations. The role of packaging changes with the increase in the use of e-commerce: from the traditional "shop window" it has become a means of information and containment of products.

The purpose of the chapter is to briefly describe a model of OM discipline usable to highlight the role of packaging along the supply chain, describing different implications of an efficient product packaging system for successful management of operations. Particular attention is paid to the role of product packaging in modern web operations.

The chapter is organised as follows: Section 2 presents a brief description of OM in order to engage the topic of packaging. The packaging logistics system is described in Section 3, before presenting experimental results of studies dealing with packaging perception by both companies and customers [2; 3]. Moreover, Section 3 introduces the packaging logistics system also including the analysis of the role of packaging in $\mathrm{OM}$ and a description of a complete mathematical model for the evaluation of total packaging cost is presented. Section 4 presents background about modern e-commerce and its relationship with OM. Packaging and e-commerce connected with OM is described in Section 5 and a case study on packaging e-commerce in operations is analysed in Section 6. Finally, the conclusion and further research are presented.

\section{Operations management in brief}

The brief introduction to OM wants to introduce the important role of packaging in all activities of a company. This section will describe a model of OM discipline that the authors have taken as a reference for dealing with the packaging topic.

According to Drejer et al. [4], the "Scientific Management" approach to industrial engineering developed by Frederick Taylor in the 1910s is widely regarded as the basis on which $\mathrm{OM}$, as a discipline, is founded. This approach involved reducing a system to its simplest elements, analysing them, and calculating how to improve each element.

$\mathrm{OM}$ is the management function applied to manufacturing, service industries and no-profit organizations [5] and is responsible for all activities directly concerned with making a product, collecting various inputs and converting them into desired outputs through operations [1]. Thus, OM includes inputs, outputs, and operations. Examples of inputs might be raw materials, money, people, machines, and time. Outputs are goods, services, staff wages, and waste materials. Operations include activities such as manufacturing, assembly, packing, serving, and training [1]. The operations can be of two categories: those that add value and those with no added value. The first category includes the product processing steps (e.g. operations that transform raw materials into good products). The second category is actually a kind of waste. Waste consists of all unnecessary movements for completing an operation, which should therefore be eliminated. Examples of this are waiting time, piling products, reloading, and movements. Moreover, it is important to underline, right from the start, that 
the packaging system can represent a source of waste, but at the same time, a possible source of opportunities. Before waste-to-energy solutions, for example, it is possible to consider the use of recycled packages for shipping products. The same package may be used more than once; for example, if a product is sent back by the consumer, the product package could be used for the next shipment.

OM can be viewed as the tool behind the technical improvements that make production efficient [6]. It may include three performance aims: efficiency, effectiveness, and customer satisfaction. Whether the organization is in the private or the public sector, a manufacturing or non-manufacturing organization, a profit or a non-profit organization, the optimal utilization of resources is always a desired objective. According to Waters [1], OM can improve efficiency of an operation system to do things right and as a broader concept. Effectiveness involves optimality in the fulfilment of multiple objectives with possible prioritization within them; it refers to doing the seven right things well: the right operation, right quantity, right quality, right supplier, right time, right place and right price. The OM system has to be not only profitable and/or efficient, but must necessarily satisfy customers.

According to Kleinforfer et al. [7], the tools and elements of the management system need to be integrated with company strategy. The locus of the control and methodology of these tools and management systems is directly associated with operations. With the growing realization of the impact of these innovations on customers and profit, operations began their transformation from a "neglected stepsister needed to support marketing and finance to a cherished handmaiden of value creation" [8].

According to Hammer [9], a wave of change began in the 1980s called Business Process Reengineering $^{1}(\mathrm{BRP})$. BPR provided benefits to non-manufacturing processes by applying the efforts that Total Quality Management ${ }^{2}$ (TQM) and Just In Time ${ }^{3}$ (JIT) had applied to manufacturing. Gradually, this whole evolution came to be known as Process Management, a name that emphasized the crucial importance of processes in value creation and management. Process management is given further impetus by the core competency movement [13], which stressed the need for companies to develop technology-based and organizational competencies that their competitors could not easily imitate. The confluence of the core competency and process management movements led to many of the past decade's changes including the unbundling of value chains, outsourcing, and innovations in contracting and supply chains. People now recognize the importance of aligning strategy and operations, a notion championed by Skinner [14].

As companies developed their core competencies and included them in their business processes, the tools and concepts of TQM and JIT have been applied to the development of new products and supply chain management [7]. Generally, companies first incorporated JIT be-

\footnotetext{
$1 \mathrm{BRP}$ is the fundamental re-thinking and radical re-design of business processes to achieve improvements in critical contemporary measures of performance, such as cost, quality, service, and speed [10].

$2 \mathrm{TQM}$ is an integrative philosophy of management for continuously improving the quality of products and processes [11].

3 JIT is a manufacturing program with the primary goal of continuously reducing, and ultimately eliminating all forms of waste [12].
} 
tween suppliers and production units. The 1980s' introduction of TQM and JIT in manufacturing gave rise to the recognition that the principles of excellence applied to manufacturing operations could also improve business processes and that organizations structured according to process management principles would improve. According to Kleindorfer et al. [7], the combination of these process management fundamentals, information and communication technologies, and globalization has provided the foundations and tools for managing today's outsourcing, contract manufacturing, and global supply chains. In the 1990s companies moved over to optimized logistics (including Efficient Consumer Response ${ }^{4}$ (ECR)) between producers and distributors, then to Customer Relationship Management ${ }^{5}$ (CRM) and finally to global fulfilment architecture and risk management. These supply chain-focused trends inspired similar trends at the corporate level as companies moved from lean operations to lean enterprises and now to lean consumption [17]. Figure 1 shows these trends and drivers, based on Kleindorfer et al. [7].

2005

Global Fulfillment Architecture and Risk Management

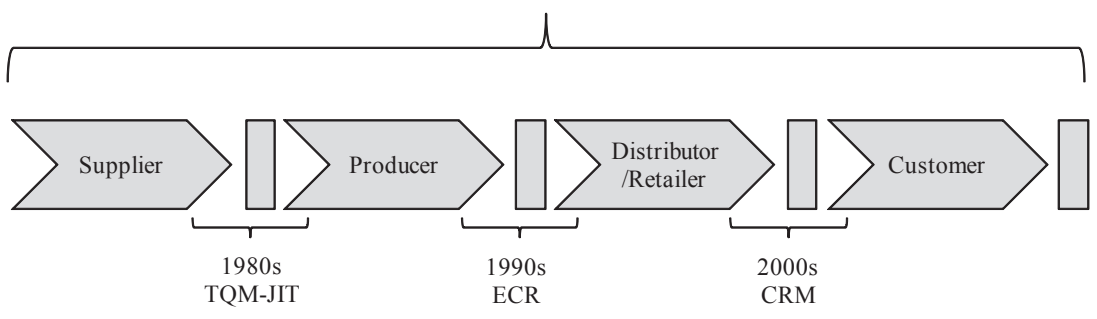

Figure 1. Trends and drivers of Operations Management (1980-2000) [7]

In order to manage the supply chain, organizations have to make different decisions about $\mathrm{OM}$ that can be classified as strategic, tactical, and operational. A graphical representation of the three decision levels of OM is shown in Figure 2 [18].

The three decisions' levels of OM interact and depend on each other: the strategic level is a prerequisite for the tactical level, and this in turn is a prerequisite for the operational level.

Strategic, tactical, and operational levels of $\mathrm{OM}$ are closely connected with the packaging system. Packaging is cross-functional to all company operations, since it is handled in several parts of the supply chain (e.g. marketing, production, logistics, purchasing, etc.). A product packaging system plays a fundamental role in the successful design and management of the operations in the supply chain. An integrated management of the packaging system from the strategic (e.g. decision of defining a new packaging solution), tactical (e.g. definition of the main packaging requirements) and operational (e.g. development of the physical

4 ECR is an attempt to increase the velocity of inventory in the packaged goods industry throughout the supply chain of wholesalers, distributors and ultimately end consumers [15].

5 CRM is a widely implemented model for managing company's interactions with customers. It involves using technology to organize, automate, and synchronize business processes [16]. 


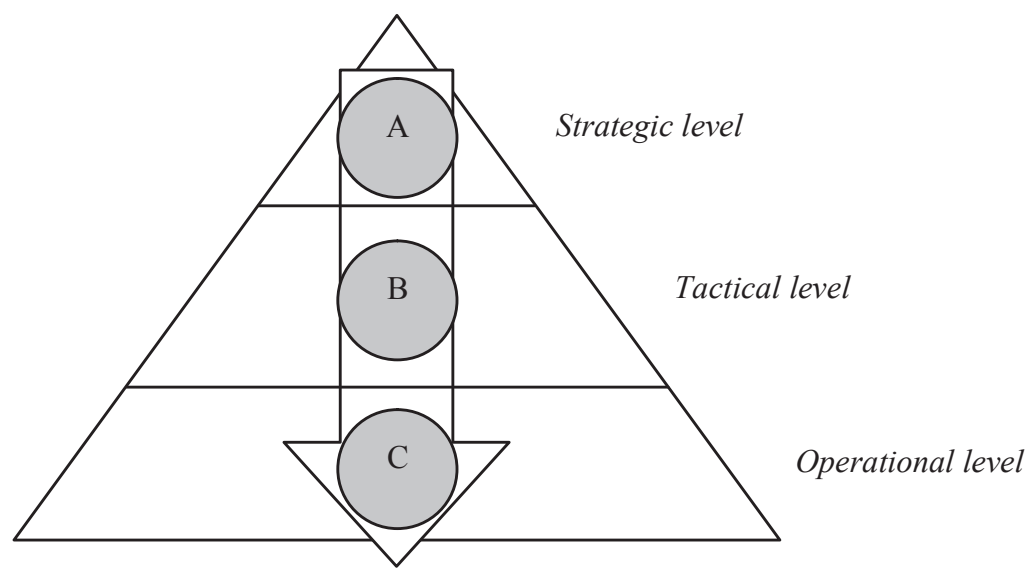

Figure 2. Graphical representation of OM's decision levels [18]

packaging system and respect of the requirements) point of view, allows companies to find the optimal management of the packaging system and to reduce packaging cost.

A general framework of product packaging and the packaging logistics system will be presented in Section 3.

\subsection{Sustainable operations management}

$\mathrm{OM}$ is increasingly connected with the environment and sustainable development (i.e. the development that meets the needs of the present without compromising the ability of future generations to meet their own needs), and it now concerns both the operational drivers of profitability and their relationship with people and the planet.

Following the definition of sustainability by the World Commission on Environment and Development (WCED), Sustainable Operations Management (SOM) is defined as the set of skills and concepts that allow a company to structure and manage its business processes in order to obtain competitive returns on its capital assets without sacrificing the needs of stakeholders and with regard for the impact of its operations on people and environment.

In order to perform sustainable operations, it is necessary to enlarge the perspective of $\mathrm{OM}$, including people and the planet. According to Kleindorfer et al. [7], SOM integrates the profit and efficiency orientation of traditional OM with broader considerations of the company's internal and external stakeholders and its environmental impact. SOM helps companies to become agile, adaptive and aligned, balancing the people and the planet with profits [7].

Figure 1 has shown the evolution of OM since the 1980s. Figure 3 shows the impact of the SOM in the supply chain [7]. SOM has emerged over recent years and it influences the entire life cycle of the product (e.g. the management of product, recovery and reverse flows). 


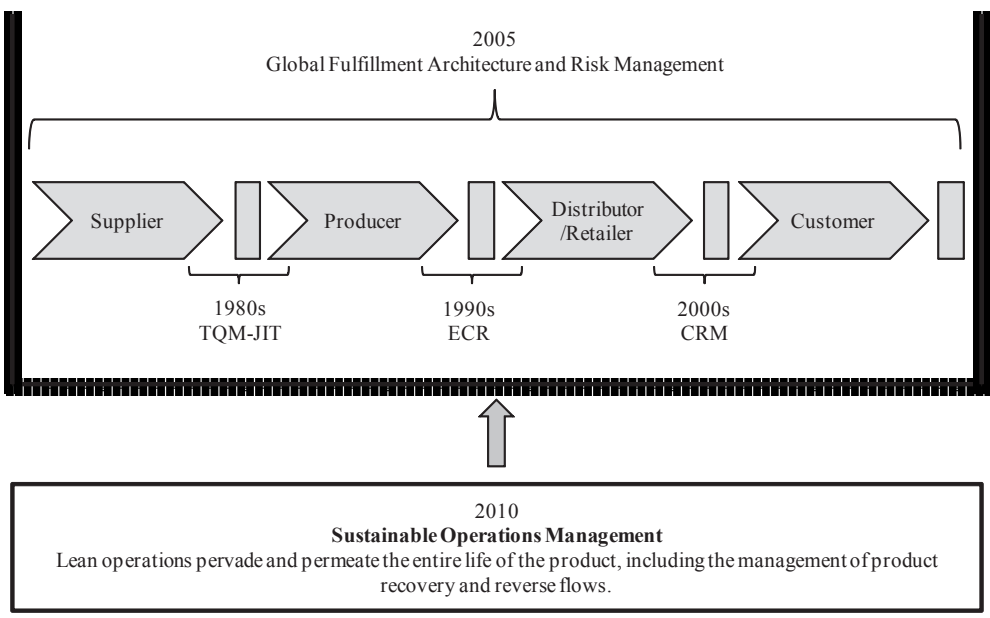

Figure 3. The impact of SOM in the supply chain (1980-2010) [7]

Considering the sustainability, environmental responsibility and recycling regulations, the packaging system plays an increasingly important role. Several environmental aspects are affected by packaging issues:

- Waste prevention: packages should be used only where needed. Usually, the energy content and material usage of the product being packaged are much greater than that of the package;

- Material minimization: the mass and volume of packages is one of the criteria to minimize during the package design process. The use of "reduced" packaging helps to reduce the environmental impacts;

- Re-use: the re-use of a package or its component for other purposes is encouraged. Returnable packages have long been used for closed loop logistics systems. Some manufacturers re-use the packages of the incoming parts for a product, either as packages for the outgoing product or as part of the product itself;

- Recycling: the emphasis focuses on recycling the largest primary components of a package: steel, aluminium, paper, plastic, etc.;

- Energy recovery: waste-to-energy and refuse-derived fuel in facilities are able to make use of the heat available from the packaging components;

- Disposal: incineration, and placement in a sanitary landfill are needed for some materials.

According to the studies conducted by Regattieri et al. [2; 3], users and companies have shown an interest in the environment and its link with the packaging system. Indeed, they believe that careful use of packaging can lead to an important reduction in environmental impact. Companies have begun to use recyclable materials (e.g. cardboard, paper, and plastic) and to re-use packages for other activities (for example online retailers are beginning to 
re-use secondary packages of back products for future shipments). The next section describes the packaging system and its crucial role for the activities along the supply chain, and then in OM.

\section{A theoretical framework of the packaging system}

During recent decades, the importance of the packaging system and its different functions has been increasing. Traditionally, packaging is intended as a means of protecting and preserving goods, handling, transport, and storage of products [19]. Other packaging functions like sales promotion, customer attention and brand communication have consistently grown in importance [20]. It means that when a packaging developer makes a package, it needs to be designed in order to meet the demand from a sales and a marketing perspective, and not only from a manufacturing process and transportation network perspective [21].

The European Federation defines packaging as all products made of any materials of any nature to be used for the containment, protection, delivery and presentation of goods, from raw materials to processed goods.

Packaging is built up as a system usually consisting of a primary, secondary, and tertiary level [22]. The primary package concerns the structural nature of the package; it is usually the smallest unit of distribution or use and is the package in direct contact with the contents. The secondary package relates to the issues of visual communication and it is used to group primary packages together. Finally, the tertiary package is used for warehouse storage and transport shipping [23].

A graphical representation of packaging system is shown in Figure 4:

The packaging system is cross-functional, since it interacts with different industrial departments, with their specific requests of how packages should be designed, and these are often contradictory. Thus, packages have to satisfy several purposes, such as:

- Physical protection: the objects enclosed in the package may require protection from mechanical shock, vibration, electrostatic discharge, compression, temperature, etc.;

- Hygiene: a barrier from e.g. oxygen, water vapour, dust, etc. is often required. Keeping the contents clean, fresh, sterile and safe for the intended shelf life is a primary function;

- Containment or agglomeration: small objects have to be grouped together in one package for efficiency reasons;

- Information transmission: packages can communicate how to use, store, recycle, or dispose of the package or product;

- Marketing: packages can be used by marketers to encourage potential buyers to purchase the product; 


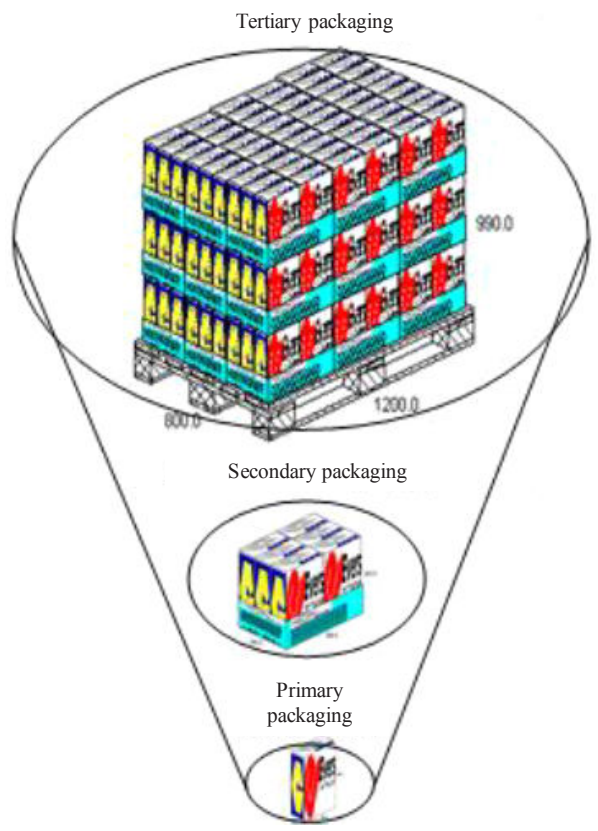

Figure 4. Graphical representation of the packaging system

- Security: packages can play an important role in reducing the risks associated with shipment. Organizations may install electronic devices like RFID tags on packages, to identify the products in real time, reducing the risk of thefts and increasing security.

\subsection{Packaging system and operations management}

In recent years, packaging design has developed into a complete and mature communication discipline [24]. Clients now realize that packages can be a central and critical element in the development of an effective brand identity. The packaging system fulfils a complex series of functions, of which communication is only one. Ease of processing and handling, as well as transport, storage, protection, convenience, and re-use are all affected by packaging.

The packaging system has significant implications in OM. In order to obtain successful management of operations, packaging assumes a fundamental role along the whole supply chain and has to be connected with logistics, marketing, production, and environment aspects. For example, logistics requires the packages to be as easy as possible to handle through all processes and for customers. Marketing demands a package that looks nice and is the right size. Packages do not only present the product on the shelf but they also arouse consumers' expectations and generate a desire to try out the product. Once the product is purchased, packages reassure the consumer of a product's quality and reinforce confidence [24]. Production requires only one size of packaging for all kinds of products in order to minimize time and labour cost. The environmental aspect demands the packaging system to be recy- 
clable and to use the least material possible. Figure 5 shows the main interactions of the packaging system.

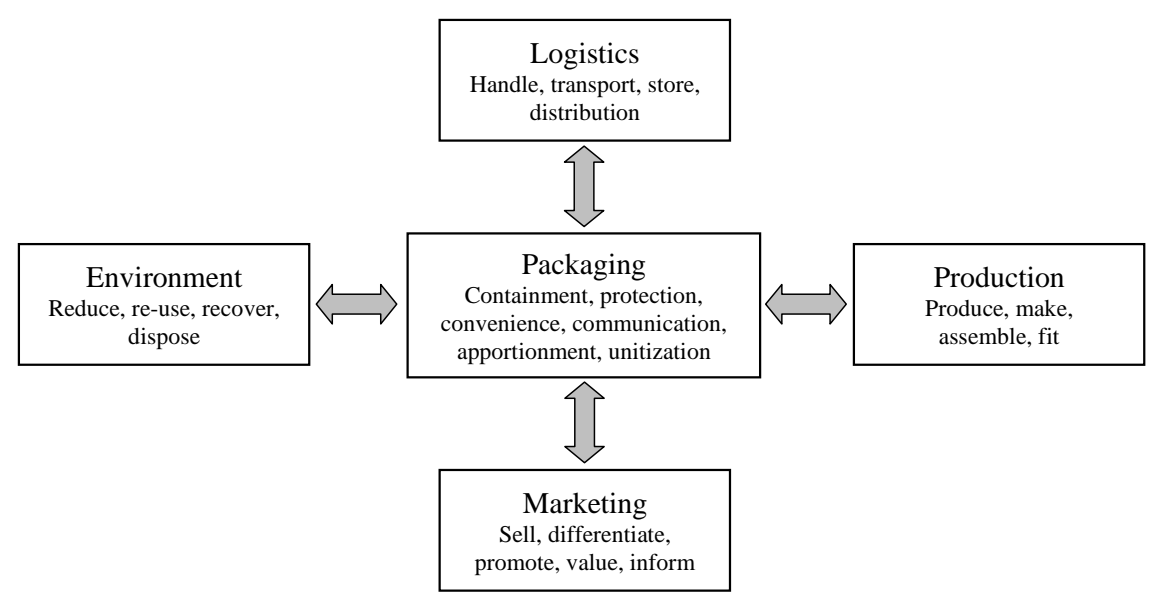

Figure 5. The main interactions of the packaging system

Scholars dealing with packaging disagree about its main function: some researchers emphasize that packaging is a highly versatile marketing tool [20], while others consider it mainly as an integral element of the logistics function [19; 25]. It is necessary to balance the technological and marketing aspects of packaging, indeed it has a significant impact on the efficiency of both logistics (e.g. manufacturing and distribution costs, time required for completing manufacturing and packing operations, which affect product lead time and due date performance to the customer) and the marketing function (e.g. products' selling, shelf presentation, etc.).

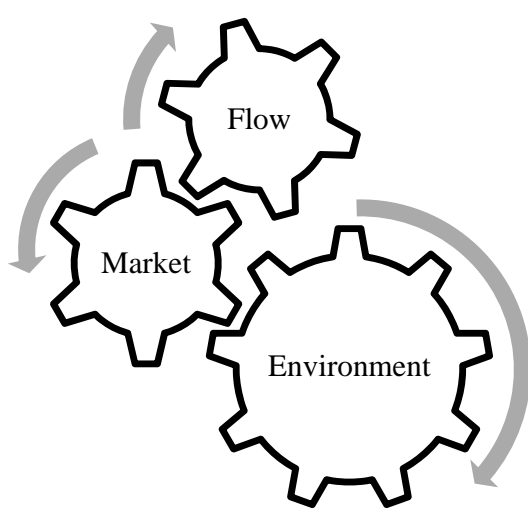

Figure 6. The main functions of the packaging system [26] 
During the recent decades, the environmental aspect is considered by companies that deal with the packaging system. According to Johansson [26] the packaging system can be divided in three main functions, that interact each other: flow, market and environment (Figure 6).

The flow function consists of packaging features that contribute to more efficient handling in distribution. Packaging logistics, internal material flows, distribution, unpacking, disposal and return handling are included in this function.

Packaging logistics is a relatively new discipline that in recent years has been developed and has gained increasing attention in terms of the strategic role of logistics in delivering competitive advantage by the industrial and scientific community [22; 25]. Industry and science attribute different maturity levels to the subject depending on country and culture. According to Saghir [22], the concept of packaging logistics focuses on the synergies achieved by integrating packaging and logistics systems with the potential of increased supply chain efficiency and effectiveness, through the improvement of both packaging and logistics related activities. A more recent definition of packaging logistics is attributed to Chan et al. [27], who describe packaging logistics as the interaction and relationship between logistics and packaging systems that improve add-on values on the whole supply chain, from raw material producers to end users, and the disposal of the empty package, by re-use, material recycling, incineration or landfill. Both the definitions $([22 ; 27])$ focus on the importance of the packaging logistics system, mainly in order to improve the efficiency of the whole supply chain.

In the market function, things like design, layout, communication, ergonomic aspects that create value for the product and the brand are important features for the packaging system [18]. The purpose of the market function is to satisfy customers and to increase product sales.

During recent decades the link between packaging and marketing is analysed in depth by several authors, and packaging has been studied as a marketing instrument that can influence some specific aspects, such as product positioning, consumer attention, categorization and evaluation, usage behaviour, intention to purchase or brand communication [28]. The aspect is significant since the package plays the role of an important interface between the brand owner and the consumer. The initial impression of product quality by the consumers is often judged by the impression of the package [29].

In the current operational environment, planning innovations must take into account not only marketing and logistics functions, but also a factor that is emerging as increasingly important: the environmental aspect. It aims to reduce the negative effects of the packaging system on the environment. Issues like the use of fewer inputs for the same outputs and the re-use of materials, facilitate the recycling of packaging [18]. Verruccio et al. [28] suggest that an increasing number of companies are choosing approaches that take care of the environmental aspects. It is further established that the design of the packaging system heavily influences the environmental aspect of activities in the supply chain [29; 30-32].

With regard to packaging logistics, the use of an appropriate packaging system (in terms of functions, materials, size and shape) can improve the management of operations [18]: 
1. Facilitate goods handling. This function considers the following aspects:

2. a. Volume efficiency: this is a function of packaging design and product shape. In order to optimize the volume efficiency of a package, this function can be split into two parts, internal and external filling degree. The first regards how well the space within a package is utilized. When using standardized packages with fixed sizes, the internal filling degree might not always be optimal. The external filling degree concerns the fitting of the primary packages with secondary and of secondary with tertiary [7]. Packages that perfectly fill each other can eliminate unnecessary handling and the risk of damage, but it is important not to be too ambitious. Too much packaging may be too expensive, and there is a point where it is less costly to allow some damage than to pack for zero damage;

3. b. Consumption adaptation: the quantity of packages must be adapted to the consumption in order to keep costs low and not to tie unnecessary capital. Moreover it is desirable to have flexible packages and a high turnover of the packaging stock [7];

4. c. Weight efficiency: the package must have the lowest possible weight, because volume and weight limit the possible amount to transport. The weight is even more important when packages are handled manually [7];

5. d. Handleability: the packaging must be easy to handle for people and automatic systems working in the supply chain, and final customers [7]. According to Regattieri et al. [2; 3], the handleability is considered the most critical packaging quality attribute by Italian companies and users;

6. Identify the product. The need to trace the position of goods during transport to the final destination can be achieved in different ways, for example by installing RFID tags in packages. Thanks to this new technology, it is possible to identify the position of both packages and products in real time. This system leads to a reduction in thefts, increase in security, mapping of the path of products and control of the work in progress;

7. Protect the product. The protection of the product is one of the basic functions of packaging for both companies and users [2; 3]. An unprotected product could cause product waste, which is negative from both the environmental and the economic point of view. Packages must protect products during manufacturing and assembly (within the factory), storage and picking (within the warehouse) and transport (within the vehicle) from surrounding conditions, against loss, theft and manipulation of goods.

\subsection{The role of packaging along the supply chain}

Due to the different implications of the packaging system with all the activities of an organization, as underlined in the previous paragraphs, packaging has to be considered an important competitive factor for companies to obtain an efficient supply chain.

The packaging function assumes a crucial role in all activities along the supply chain (e.g. purchase, production, sales, transport, etc.). It is transversal to other industrial functions such as logistics, production, marketing and environmental aspects. The packaging function 
has to satisfy different needs and requirements, trying to have a trade-off between them. Considering the simplified supply chain of a manufacturing company (Figure 7), it is possible to analyse the role of the packaging function for all the parties of the supply chain.

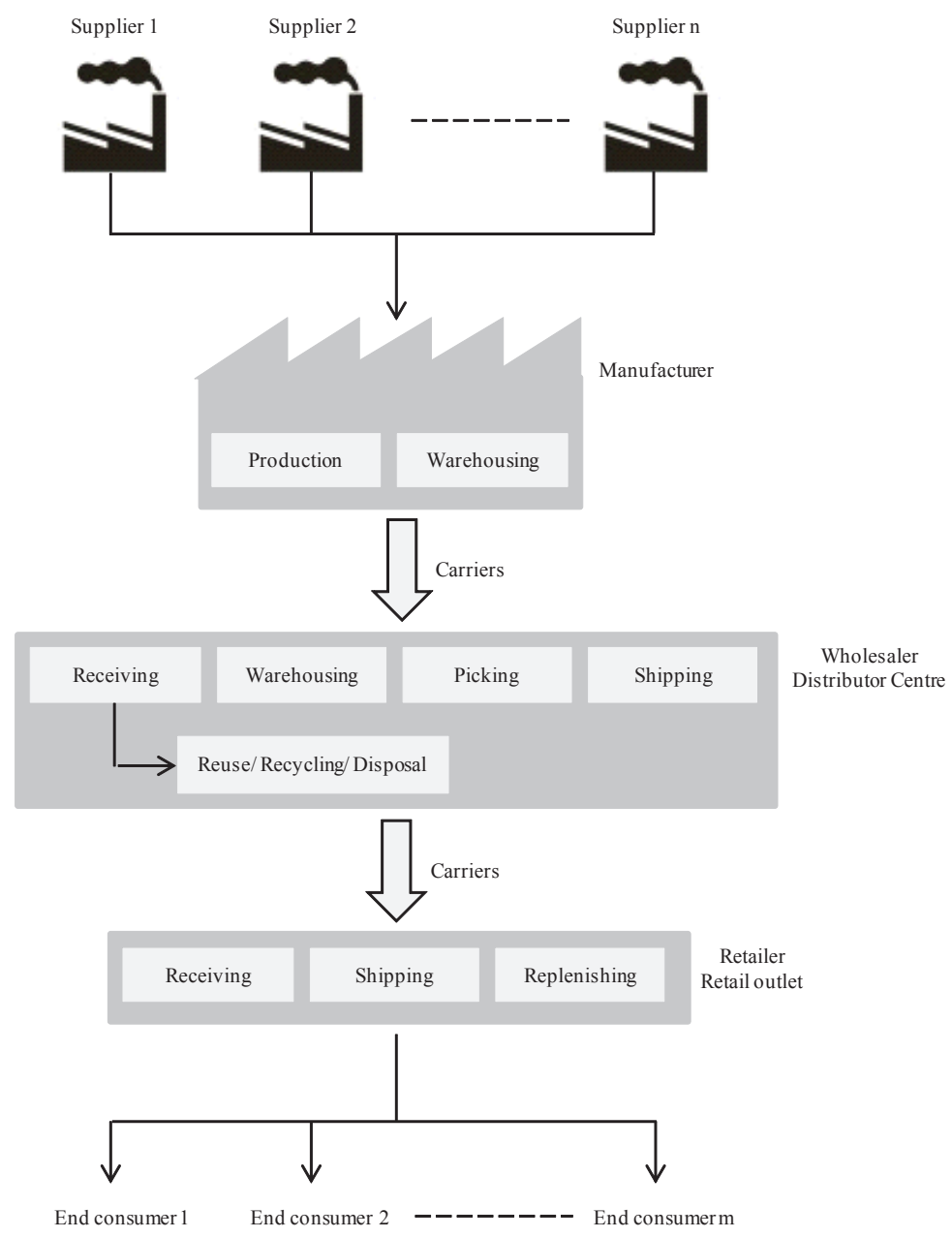

Figure 7. Typical supply chain of a manufacturing company

$N$ suppliers provide raw materials to the manufacturer, which produces the finished products, sold to the distribution centre, then to the retailer and finally to $m$ end consumers. In the middle, there are carriers that transport and distribute finished products along the supply chain. Each party has different interests and requirements regarding the function of packaging. Table 1 shows the different role of packaging for the parties to the supply chain. 


\begin{tabular}{|c|c|}
\hline Party & Role of packaging \\
\hline n Suppliers & $\begin{array}{l}\text { Suppliers are more interested in the logistics aspect of packaging than in marketing. They have to } \\
\text { send products to the manufacturer and their purpose is the minimization of the logistics costs } \\
\text { (transport, distribution, warehousing), so they prefer a package that is easy to handle and } \\
\text { transport. }\end{array}$ \\
\hline Manufacturer & $\begin{array}{l}\text { The manufacturer produces finished products to sell to the distribution centre and, indirectly, to } \\
\text { end consumers. It is important for the manufacturer to take into account all aspects: } \\
\text { - product protection and safety, } \\
\text { - logistics, } \\
\text { - marketing and the } \\
\text { - environment. } \\
\text { Product protection and safety: the packages have to protect and contain the product, } \\
\text { withstanding mechanical shocks and vibrations; } \\
\text { Logistics: the manufacturer has to handle, store, pick and transport the product to the } \\
\text { distribution centre. He has to make primary, secondary and tertiary packaging that is easy to } \\
\text { transport, minimizes logistics costs and improves the efficiency of the company; } \\
\text { Marketing: the manufacturer has to sell its products to the distribution centre that in turn sells to } \\
\text { the retailer and in turn to end consumers. The manufacturer is indirectly in contact with end } \\
\text { consumers and has to make primary packaging (the package that the users see on the shelf) that } \\
\text { can incite the consumer to buy that product instead of another one. As Pilditch [33] said, the } \\
\text { package is a "silent salesman", the first thing that the consumer sees when buying a product; } \\
\text { Environment: people are more and more careful about protecting the environment. The } \\
\text { manufacturer has to study a package that minimizes the materials used and can be re-usable or } \\
\text { recyclable. } \\
\text { The manufacturer has to balance the aspects described above in order to obtain an efficient } \\
\text { supply chain. }\end{array}$ \\
\hline Wholesaler & $\begin{array}{l}\text { The wholesaler purchases products from the manufacturer and transports them to the } \\
\text { distribution centre. He is mainly interested in the logistics aspect of packages since the most } \\
\text { important functions are warehousing, picking and shipping the products. The wholesaler needs a } \\
\text { package that is easy to handle and transport rather than one with an attractive shape and design. }\end{array}$ \\
\hline Retailer & $\begin{array}{l}\text { The retailer has to sell products to end consumers and for this reason, needs to consider what } \\
\text { interests the end consumers. Marketing and environmental aspects are important: marketing } \\
\text { because the package is a "shop window" for the product; environment since people are careful } \\
\text { about minimizing pollution preferring to buy products contained in recyclable or re-usable } \\
\text { packages. }\end{array}$ \\
\hline$m$ End consumers & $\begin{array}{l}\text { End consumers are interested in marketing (indeed primary and secondary packages are effective } \\
\text { tools for marketing in real shops [33]) and environmental aspects. }\end{array}$ \\
\hline
\end{tabular}

Table 1. The role of packaging for the parties along the supply chain

In conclusion, the packaging system plays a fundamental role along the entire supply chain where the parties often have opposite requirements and needs. Its design can be considered 
an element of $\mathrm{OM}$ discipline and must be integrated in the product design process taking into account logistics, production, marketing and environmental needs.

\subsection{The perception of packaging by Italian companies and consumers $[2 ; 3]$}

Regattieri et al. $[2 ; 3]$ conducted two studies about the perception of packaging by Italian companies and users. The first deals with how Italian companies perceive and manage the packaging system, while the second discuss how Italian users perceive packaging quality attributes. The next two paragraphs briefly present the analysis conducted.

\subsubsection{Packaging perception by Italian companies [2]}

The study conducted by Regattieri et al. [2] is based on an explorative study of packaging development and packaging logistics, conducted in several Italian companies, from different industrial sectors. After the analysis of the Italian situation, the findings have been compared with the corresponding situation in Sweden. The comparison is mainly based on previous research conducted at the packaging logistics division of Lund University [34; 35].

In order to discuss the Italian industrial situation in terms of the packaging system, the authors implemented a questionnaire on packaging and its relationship with logistics, product and the environment. The quantitative content analysis of questionnaires allowed the authors to look in more depth at the Italian situation concerning packaging.

The first interesting data to underline is that more than half of companies (52.1\%) think that packaging and its functions are critical and that their sales even depend on packaging $(52.2 \%)$.

Another interesting analysis relates to packaging functions: protection and containment of the product are considered the most relevant function of packaging since it has effects on all activities throughout the supply chain, followed by product handling and communication (Figure 8). Like Italian companies, the packaging function most frequently mentioned by Swedish industries is the protection of products [34].

In order to obtain significant results on the product handling function, it is necessary to codesign product and packaging development. Companies are aware of the importance of integrating the development of the product with the development of the package: although a large percentage of Italian companies think the integration packaging and product is important and could reduce costs during the product life cycle, only $34.8 \%$ of them develop the packaging and the product at the same time. Italian companies, unlike Swedish ones, usually develop packaging after the designing the product.

In the same way as Swedish industries [34], Italian companies also consider logistics and transport an important packaging function. Indeed, $86.3 \%$ of companies report evaluating packaging costs from the transport point of view, mainly focusing on compatibility with vehicles and protection of goods (Figure 9). This data underlines the importance of the link between packaging and logistics systems: companies know that packaging (in terms of material, shape and size) influences storage, transport and distribution of goods. Although 


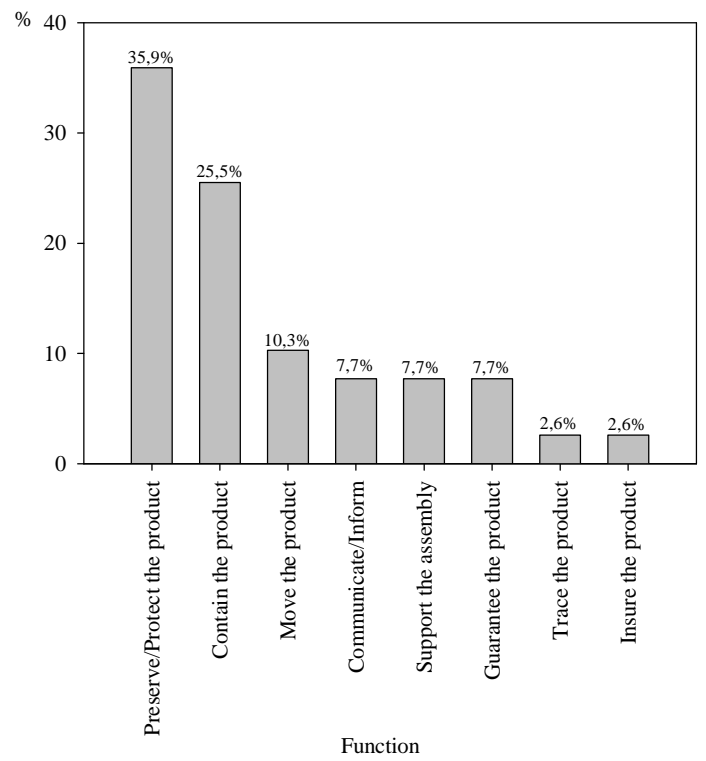

Figure 8. Classification of packaging functions

the most respondents compute packaging costs from the logistics point of view, only $39.1 \%$ of them report evaluating the total cost of packaging.

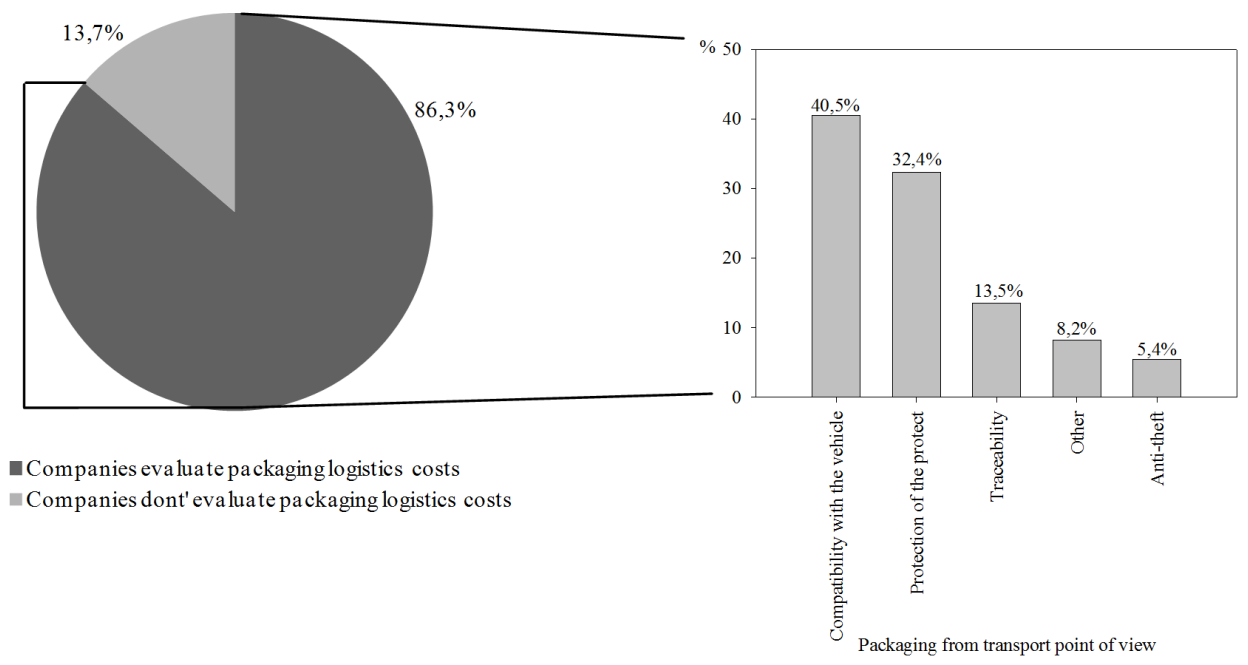

Figure 9. Classification of evaluating packaging logistics cost 
The questionnaire also pointed out the importance of the relationship between packaging and the environment: $77.3 \%$ of Italian companies report using methods and applications in order to evaluate environmental aspects and $56.5 \%$ report recycling packaging materials. It is still a low percentage compared with Swedish data: in Sweden, consumer packages are largely recycled (e.g. $90 \%$ of glass, $73 \%$ of metal and $74 \%$ of paper and cardboard packages [36]).

The comparison between Italian and Swedish industries' perception of packaging has highlighted both Sweden's long-standing tradition in packaging development and in packaging logistics research and practice and the increasing attention of Italian industries on the importance of packaging functions (e.g. logistics and environmental aspects). Italian companies are following the Swedish ones in the development of a packaging logistics system and in the integration of packaging and product development, while maintaining their own characteristics. For more details, see Regattieri et al. [2].

\subsubsection{Packaging perception by Italian customers [3]}

The second analysis conducted by Regattieri et al. [3] is based on an explorative study conducted through a questionnaire distributed to Italian users. In order to understand how customer satisfaction may be increased, the authors analysed Italian consumers' perception of packaging quality attributes using the Theory of Attractive Quality, developed by Kano et al. in 1984 [37]. The findings are then compared with those of Swedish customers [38].

Kano et al. [37] defined a quality perspective in which quality attributes are divided into different categories, based on the relationship between the physical fulfilment of a quality attribute and the perceived satisfaction of that attribute. The five categories are attractive, onedimensional, must-be, indifferent and reverse quality. All quality attributes can be satisfied or dissatisfied independently and they can change from one status to another according to the changes in customers' perspective. The packaging quality attributes are classified into three entities: technical (e.g. protection of the product, use of recyclable materials), ergonomic (everything relating to adaptations to human behaviour when using the product (e.g. ease of grip, ease of opening, user-friendly)) and communicative (the packaging's ability to communicate with customers (e.g. use of symbols, instructions for using packaging, brand communication)).

The questionnaire is made up of three parts:

- General information about the customers;

- Functional and dysfunctional question about packaging quality attributes. The classification into attractive $(\mathrm{A})$, one-dimensional $(\mathrm{O})$, must-be $(\mathrm{M})$, indifferent $(\mathrm{I})$, reverse $(\mathrm{R})$ and questionable (Q) (Q responses include sceptical answers (Kano et al., 1984)) is made using an evaluation table (Figure 10), adapted by Löfgren and Witell [38] from Berger et al. [39].

- Level of importance of packaging characteristics: customers had to assign a value between 1 (not important) and 10 (very important) to the packaging quality attributes. 


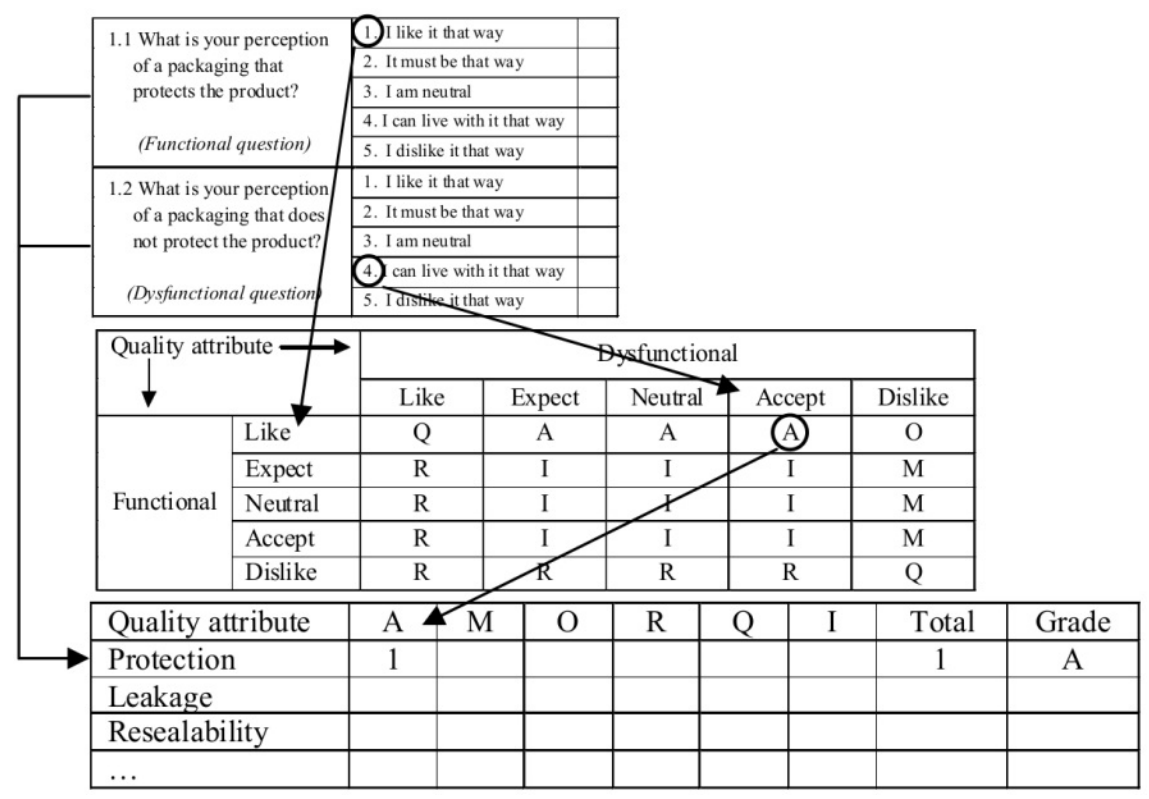

Figure 10. Evaluation table to classify packaging quality attributes (table adapted by [38] from [39])

The analysis of the questionnaires shows that Italian users are mainly interested in the ergonomic entity, made up of packaging characteristics that permit easy of handling of the product. Italians believe that the most important packaging function is protection of the product, according to the traditional role that has always been attributed to the packaging function.

For each packaging quality attribute, better and worse average values are calculated, indicating whether customer satisfaction can be increased by satisfying a certain requirement (better) or whether fulfilling this requirement may merely prevent customer dissatisfaction (worse) [39].

Better average $=\frac{\sum_{i=1}^{n}(A+O)}{\sum_{i=1}^{n}(A+O+M+I)} \forall j \quad$ Worse average $=\frac{\sum_{i=1}^{n}(M+O)}{\sum_{i=1}^{n}(A+O+M+I)} \forall j$

$\mathrm{i}=1, \ldots, \mathrm{n}$ is the number of responses for each packaging quality attribute

$\mathrm{j}=1, \ldots, \mathrm{m}$ represents packaging quality attributes

Figure 11 shows the Worse-Better Diagram for Italian users.

The Worse-Better Diagram focuses on technical, ergonomic and communicative entities. Contrary to the ergonomic and communicative entities, it is not possible to identify a definite cluster for the technical group, since the packaging quality attributes are scattered in the diagram, moving from one-dimensional (e.g. recyclable materials) to indifferent (e.g. additional functions) to must-be (e.g. protection of the product). Ergonomic and communicative 


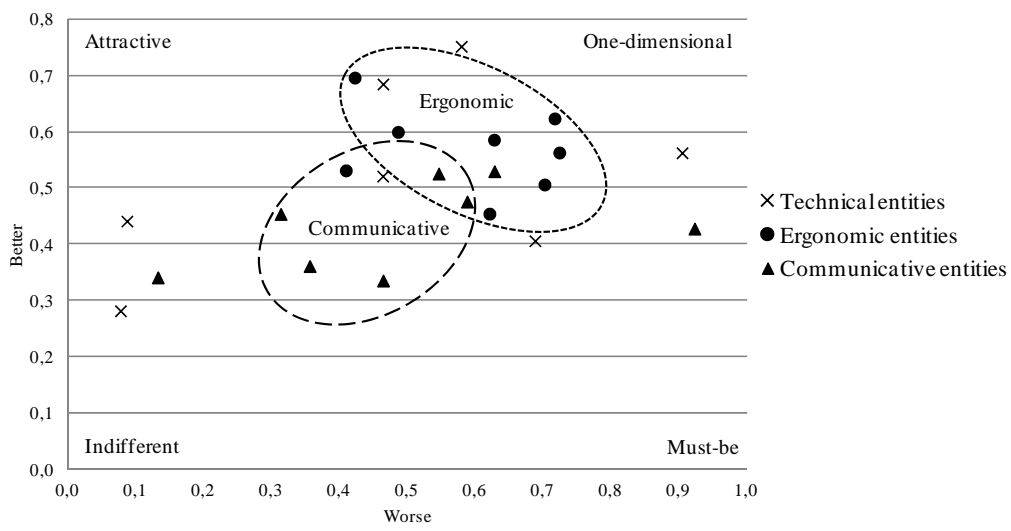

Figure 11. Worse-Better diagram for Italian perception on packaging quality attributes

entities assume definite clusters in the Worse-Better Diagram: the packaging quality attributes belonging to the ergonomic entity are mainly classified as one-dimensional. They are distinctive attributes that customers consider during the purchase of a product, comparing different brands. Italian customers locate the communicative quality attributes in the middle of the diagram. They delineate a specific cluster, but the dimension to which they belong is not clear.

Another important analysis is the level of importance attributed by Italian users to each packaging quality attribute. The highest values of importance are assigned to the protection of the product (9.59), open-dating (9.47), and hygiene (9.52). Italian customers seem to be interested neither in the aesthetics of packaging (attractive and nice looking print and the aesthetic appeal have low levels of importance: 4.52 and 5.00 respectively) nor in the additional functions (5.80).

From the comparison with the Swedish results [38], both Italians and Swedes have similar behaviour in terms of perception of packaging quality attributes. They consider the ergonomic quality characteristics the most significant packaging attributes, and the protection of the product the most important packaging function. Italians also perceive the use of recyclable material another important packaging attribute, in line with the growing importance of environmental considerations. Neither Italians nor Swedes place importance on aesthetics. For more details, see Regattieri et al. [3].

\subsection{A mathematical model for packaging cost evaluation}

As the previous paragraphs have underlined, the packaging system has numerous implications along the supply chain (e.g. marketing, production, logistics, purchasing, etc.). In order to define optimal management of the packaging system, it is necessary to evaluate the total packaging cost, made up of e.g. purchasing cost, manufacturing cost, transport and labour cost, management cost, etc. The study conducted by Regattieri et al. [2] underlines that most 
companies do not estimate the total packaging costs and, to confirm this, literature analysis shows the lack of a complete function for calculating the total cost of packaging in a company. For this reason, the authors have developed a complete mathematical model, considering all the cost parameters regarding the packaging system (primary, secondary and tertiary packages and accessories) along the whole supply chain of a manufacturing company.

The model represents added value for companies seeking to estimate the total costs of their packaging system and consequently its impact on total company costs. Moreover, it may be possible to find out the overlooked and oversized packaging factors. The former should be introduced in the calculation of the total packaging costs, while the latter could be reduced or eliminated.

Figure 12 shows the simplified supply chain of a manufacturing company.

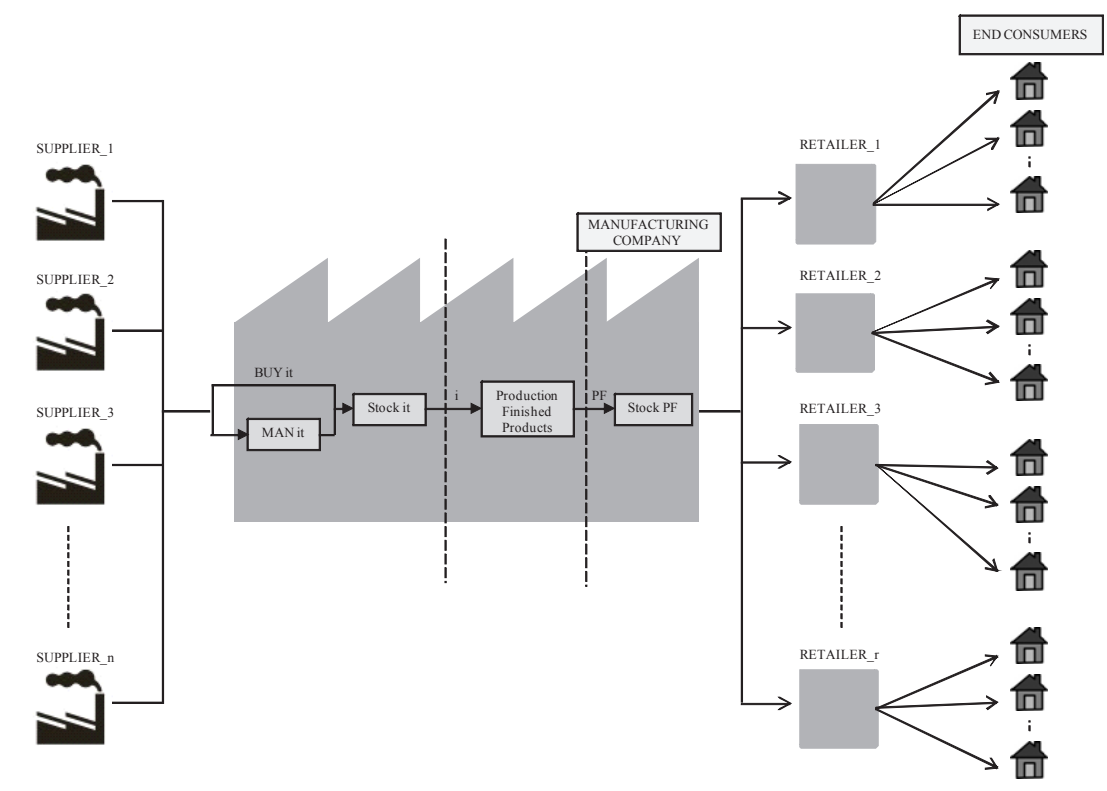

Figure 12. Simplified supply chain of a manufacturing company

The manufacturing company can rent or purchase packages (primary, secondary and tertiary and accessories) and raw materials (if the manufacturer produces packages internally) from the supplier $n$. When goods arrive, they are received in the manufacturer's receiving area, sorted and stored in the warehouse. If the company has to produce the packaging, the raw materials are picked and brought to the manufacturing area, where packages are made and subsequently stored in the warehouse. The raw materials not used during the manufacturing stage are brought back to the warehouse, creating a reverse flow of materials. When the finished products are produced, the packages are picked from the warehouse and brought to the manufacturing area. The packages not used during the manufacturing stage 
are brought back to the warehouse, creating a reverse flow of materials. The finished products are packed, put onto a pallet, and delivered to the retailer $m$. The model considers the possibility to re-use packages after the delivery of the finished products to the final customers and the possible disposal of packages if they are damaged. In addition, the model considers the possibility for the manufacturer to make a profit from sub-products derived from the disposal of packages and/or from the sale of tertiary packages to the final customers.

Table 2, 3 and 4 describe the indices, variables and cost parameters used in the model.

\begin{tabular}{|c|c|c|}
\hline Index & Domain & Description \\
\hline i & $1, \ldots, 4$ & $\begin{array}{l}\text { Level of package: } \\
\mathrm{i}=1 \text { (primary package) } \\
\mathrm{i}=2 \text { (secondary } \\
\text { package) } \\
\mathrm{i}=3 \text { (tertiary package) } \\
\mathrm{i}=4 \text { (accessories) }\end{array}$ \\
\hline $\mathrm{t}$ & $1, \ldots, \mathrm{m}$ & $\begin{array}{l}\text { Different packages for } \\
\text { each level i }\end{array}$ \\
\hline$n$ & $1, \ldots, 5$ & Suppliers \\
\hline$r$ & $1, \ldots, q$ & Retailers \\
\hline
\end{tabular}

Table 2. Indices of the model

\begin{tabular}{|c|c|c|c|}
\hline Variable & Units & Description & Domain \\
\hline$x_{\text {nit }}$ & [pieces/year] & $\begin{array}{l}\text { Quantity of raw materials } \\
\text { bought by the company from } \\
\text { the supplier } n \text { to produce } \\
\text { package i of type } t \text {. }\end{array}$ & $\begin{array}{c}\mathrm{i}=1, \ldots, 4 ; \mathrm{t}=1, \ldots, \mathrm{m} ; \\
\mathrm{n}=1, \ldots, \mathrm{s}\end{array}$ \\
\hline$x_{i t}^{\prime}$ & [pieces/year] & $\begin{array}{l}\text { Quantity of package i of type } t \\
\text { produced by the } \\
\text { manufacturer company from } \\
\text { raw materials. }\end{array}$ & $i=1, \ldots, 4 ; t=1, \ldots, m$ \\
\hline$y_{\text {nit }}$ & [pieces/year] & $\begin{array}{l}\text { Quantity of package i of type } t \\
\text { bought by the company from } \\
\text { supplier } n \text {. }\end{array}$ & $\begin{array}{c}\mathrm{i}=1, \ldots, 4 ; \mathrm{t}=1, \ldots, \mathrm{m} ; \\
\mathrm{n}=1, \ldots, \mathrm{s}\end{array}$ \\
\hline$W_{\text {nit }}$ & [pieces/year] & $\begin{array}{l}\text { Quantity of package i of type } t \\
\text { rented by the company from } \\
\text { the supplier } n \text {. }\end{array}$ & $\begin{array}{c}\mathrm{i}=1, \ldots, 4 ; t=1, \ldots, \mathrm{m} ; \\
\mathrm{n}=1, \ldots, \mathrm{s}\end{array}$ \\
\hline$r_{i t}$ & [pieces/year] & $\begin{array}{l}\text { Quantity of disposed package } \\
\text { i of type } t \text { from which the }\end{array}$ & $i=1, \ldots, 4 ; t=1, \ldots, m$ \\
\hline
\end{tabular}




\begin{tabular}{|c|c|c|c|}
\hline Variable & Units & Description & Domain \\
\hline & & $\begin{array}{l}\text { company has a profit from } \\
\text { sub-products. }\end{array}$ & \\
\hline$u_{\text {rit }}$ & [pieces/year] & $\begin{array}{l}\text { Quantity of package i of type } t \\
\text { sold by the company to the } \\
\text { retailer } r \text {. }\end{array}$ & $\begin{array}{c}i=1, \ldots, 4 ; t=1, \ldots, m ; \\
r=1, \ldots, q\end{array}$ \\
\hline $\mathrm{N}_{\mathrm{ORD}}$ & $\begin{array}{l}\text { [orders/ } \\
\text { year] }\end{array}$ & $\begin{array}{l}\text { Number of orders for buying } \\
\text { raw materials and/or } \\
\text { packages i of type t. }\end{array}$ & \\
\hline $\mathrm{N}_{\text {EXT TRAN nit }}$ & [trips/year] & $\begin{array}{l}\text { Number of trips of raw } \\
\text { materials and/or packages i of } \\
\text { type t from the supplier } n \text { to } \\
\text { the manufacturer. }\end{array}$ & $\begin{array}{c}\mathrm{i}=1, \ldots, 4 ; \mathrm{t}=1, \ldots, \mathrm{m} ; \\
\mathrm{n}=1, \ldots, \mathrm{s}\end{array}$ \\
\hline $\mathrm{N}_{\text {INT TRAN it }}$ & [trips/year] & $\begin{array}{l}\text { Number of trips of raw } \\
\text { materials and/or packages i of } \\
\text { type t from the } \\
\text { manufacturer's receiving area } \\
\text { to the warehouse. }\end{array}$ & $i=1, \ldots, 4 ; t=1, \ldots, m$ \\
\hline $\mathrm{N}_{\text {INT TRAN }}{ }^{1}$ it & [trips/year] & $\begin{array}{l}\text { Number of trips of raw } \\
\text { materials i of type } t \text { from the } \\
\text { warehouse to the } \\
\text { manufacturing area to } \\
\text { produce packages from } \mathrm{x}_{\mathrm{it}} \text {. }\end{array}$ & $i=1, \ldots, 4 ; t=1, \ldots, m$ \\
\hline$N_{\text {INT TRAN }}{ }^{2}$ it & [trips/year] & $\begin{array}{l}\text { Number of trips of packages i } \\
\text { of type t produced by the } \\
\text { manufacturer and transported } \\
\text { from the production area to } \\
\text { the warehouse. }\end{array}$ & $\mathrm{i}=1, \ldots, 4 ; \mathrm{t}=1, \ldots, \mathrm{m}$ \\
\hline $\mathrm{N}_{\text {INT TRAN }}{ }^{3}$ it & [trips/year] & $\begin{array}{l}\text { Number of trips of packages } \\
\text { (produced/bought/rented) i } \\
\text { of type t from the warehouse } \\
\text { to the production area in } \\
\text { order to support finished } \\
\text { products. }\end{array}$ & $\mathrm{i}=1, \ldots, 4 ; \mathrm{t}=1, \ldots, \mathrm{m}$ \\
\hline$N_{\text {REV INT TRAN }}{ }^{2}$ it & [trips/year] & $\begin{array}{l}\text { Number of trips of packages i } \\
\text { of type t not used during the } \\
\text { production of finished } \\
\text { products and transported } \\
\text { from the manufacturing area } \\
\text { to the warehouse. }\end{array}$ & $\mathrm{i}=1, \ldots, 4 ; \mathrm{t}=1, \ldots, \mathrm{m}$ \\
\hline
\end{tabular}




\begin{tabular}{|c|c|c|c|}
\hline Variable & Units & Description & Domain \\
\hline $\mathrm{N}_{\text {REV INT TRAN }}{ }^{1}$ it & [trips/year] & $\begin{array}{l}\text { Number of trips of the } \\
\text { quantity of raw materials i of } \\
\text { type t not used during the } \\
\text { production of packages and } \\
\text { transported from the } \\
\text { manufacturing area to the } \\
\text { warehouse. }\end{array}$ & $i=1, \ldots, 4 ; t=1, \ldots, m$ \\
\hline$N_{\text {REV EXT TRAN rit }}$ & [trips/year] & $\begin{array}{l}\text { Number of trips of packages i } \\
\text { of type } t \text { from the retailer } r \text { to } \\
\text { the manufacturer. }\end{array}$ & $\begin{array}{c}\mathrm{i}=1, \ldots, 4 ; \mathrm{t}=1, \ldots, \mathrm{m} ; \\
r=1, \ldots, \mathrm{q}\end{array}$ \\
\hline
\end{tabular}

Table 3. Variables of the model

\begin{tabular}{|c|c|c|c|}
\hline Parameter & Nomenclatures & Units & Description \\
\hline$C_{E N G}$ & $\begin{array}{l}\text { Cost of } \\
\text { Engineering }\end{array}$ & {$[€ /$ year $]$} & $\begin{array}{l}\text { Cost for studying each type of packaging and for making prototypes. It } \\
\text { includes the labour costs of engineering the product. }\end{array}$ \\
\hline $\mathrm{C}_{\mathrm{ORD}}$ & $\begin{array}{l}\text { Cost of Purchase } \\
\text { Order }\end{array}$ & [€/order] & $\begin{array}{l}\text { Cost for managing the internal purchase orders if the manufacturer } \\
\text { produces the packaging internally; otherwise it represents the purchase } \\
\text { orders for buying and/or renting packaging from suppliers. It includes the } \\
\text { labour costs for making the order. }\end{array}$ \\
\hline$C_{\text {PUR }}$ & $\begin{array}{l}\text { Cost of } \\
\text { Purchasing }\end{array}$ & {$[€ /$ piece $]$} & Purchase cost of raw materials (to produce packaging) and/or packages. \\
\hline$C_{\text {RENT }}$ & Cost of Rent & {$[€ /$ piece $]$} & Cost to rent packages. \\
\hline$C_{\text {EXt TRAN }}$ & $\begin{array}{l}\text { Cost of External } \\
\text { Transport }\end{array}$ & {$[€ /$ travel] } & $\begin{array}{l}\text { Cost for transporting raw materials and/or packages from the supplier to } \\
\text { the manufacturer: it comprises labour costs, depreciation of vehicles (e.g. } \\
\text { truck), cost of the distance travelled. }\end{array}$ \\
\hline$C_{\text {REC }}$ & Cost of Receiving & [€/year] & $\begin{array}{l}\text { Cost for receiving raw materials and/or packages. It includes the labour } \\
\text { costs and depreciation of vehicles (e.g. truck, forklift) used to unload } \\
\text { products. }\end{array}$ \\
\hline $\mathrm{C}_{\mathrm{COND}}$ & $\begin{array}{l}\text { Cost of } \\
\text { Conditioning }\end{array}$ & {$[€ /$ year $]$} & $\begin{array}{l}\text { Cost for sorting raw materials and/or packages before storing them in the } \\
\text { warehouse. It includes the labour costs and depreciation of mechanical } \\
\text { devices (if used), for example for unpacking and re-packing products. }\end{array}$ \\
\hline$C_{\text {INT TRAN }}$ & $\begin{array}{l}\text { Cost of Internal } \\
\text { Transport }\end{array}$ & {$[€ /$ travel] } & $\begin{array}{l}\text { Cost for transporting raw materials and/or packages from the } \\
\text { manufacturer's receiving area to the warehouse. It includes the labour } \\
\text { costs, depreciation of vehicles (e.g. forklift), cost of the distance travelled. }\end{array}$ \\
\hline $\mathrm{C}_{\text {StOCK }}$ & Cost of Stocking & {$[€ /$ piece $]$} & $\begin{array}{l}\text { Cost for storing raw materials and/or packages in the warehouse. It } \\
\text { includes the labour costs and the cost of the space for storing the } \\
\text { packages. }\end{array}$ \\
\hline$C_{\text {PICK }}$ & Cost of Picking & {$[€ /$ piece $]$} & $\begin{array}{l}\text { Cost for picking raw materials from the warehouse for producing the } \\
\text { packages. It includes the labour costs and depreciation of vehicles (e.g. } \\
\text { forklift) for picking the products. }\end{array}$ \\
\hline
\end{tabular}




\begin{tabular}{|c|c|c|c|}
\hline Parameter & Nomenclatures & Units & Description \\
\hline $\mathrm{C}_{\text {INT TRAN }}{ }^{1}$ & $\begin{array}{l}\text { Cost of Internal } \\
\text { Transport }\end{array}$ & {$[€ /$ travel] } & $\begin{array}{l}\text { Cost for transporting raw materials from the warehouse to the } \\
\text { manufacturing area to produce the packages. It includes the labour costs, } \\
\text { depreciation of vehicles (e.g. forklift), cost of the distance travelled. }\end{array}$ \\
\hline$C_{\text {MAN }}$ & $\begin{array}{l}\text { Cost of Packages } \\
\text { Manufacturing }\end{array}$ & {$[€ /$ piece $]$} & $\begin{array}{l}\text { Cost for producing packages internally; it includes the labour costs, } \\
\text { depreciation of production plants and utilities (e.g. electricity, water, gas, } \\
\text { etc.). }\end{array}$ \\
\hline$C_{\text {REV }}{ }^{1}$ & $\begin{array}{l}\text { Cost of Internal } \\
\text { Reverse Logistics }{ }^{1}\end{array}$ & {$[€ /$ travel] } & $\begin{array}{l}\text { Cost of transport for bringing the raw materials not used during } \\
\text { manufacturing back to the warehouse. It includes: } \\
C_{\text {REVINT TRAN }} \text { : the cost of transport for coming back to the warehouse. It } \\
\text { comprises labour costs, depreciation of vehicles used (e.g. forklift), cost of } \\
\text { the distance travelled; } \\
C_{\text {REVINT COND }}{ }^{1:} \text { the cost of conditioning packages to make them re-usable. It } \\
\text { comprises the labour costs and depreciation of mechanical devices (if } \\
\text { used), for example for unpacking and re-packing products. }\end{array}$ \\
\hline$C_{\text {INT TRAN }}{ }^{2}$ & $\begin{array}{l}\text { Cost of Internal } \\
\text { Transport }{ }^{2}\end{array}$ & {$[€ /$ travel] } & $\begin{array}{l}\text { Cost for transporting the packages produced by the company from the } \\
\text { production area to the warehouse. It includes the labour costs, } \\
\text { depreciation of vehicles (e.g. forklift), cost of the distance travelled. }\end{array}$ \\
\hline $\mathrm{C}_{\text {StOCK }}{ }^{1}$ & Cost of Stocking ${ }^{1}$ & {$[€ /$ piece $]$} & $\begin{array}{l}\text { Cost for stocking packages produced internally by the company. It includes } \\
\text { the labour costs and cost of the space for storing the packages. }\end{array}$ \\
\hline$C_{\text {PICK }} 1$ & Cost of Picking ${ }^{1}$ & {$[€ /$ piece $]$} & $\begin{array}{l}\text { Cost for picking packages (produced/bought/rented) from the } \\
\text { warehouse. It includes the labour costs and depreciation of vehicles (e.g. } \\
\text { forklift) for picking the packages. }\end{array}$ \\
\hline$C_{\text {INT TRAN }}{ }^{3}$ & $\begin{array}{l}\text { Cost of Internal } \\
\text { Transport }\end{array}$ & {$[€ /$ travel $]$} & $\begin{array}{l}\text { Cost for transporting packages from the warehouse to the manufacturing } \\
\text { area. It includes the labour costs, depreciation of vehicles (e.g. forklift), cost } \\
\text { of the distance travelled. }\end{array}$ \\
\hline$C_{R E V}^{2}$ & $\begin{array}{l}\text { Cost of Internal } \\
\text { Reverse Logistics }{ }^{2}\end{array}$ & [€/travel] & $\begin{array}{l}\text { Cost of transport for bringing packages not used during the } \\
\text { manufacturing of finished products back to the warehouse. It includes: } \\
C_{\text {REVINT TRAN }}{ }^{2} \text { : the cost of transport for coming back to the warehouse. It } \\
\text { comprises the labour costs, depreciation of vehicles used, cost of the } \\
\text { distance travelled; } \\
C_{\text {REVINT COND }}{ }^{2} \text { : the cost of conditioning packages to make them re-usable. It } \\
\text { comprises the labour costs and depreciation of mechanical devices (if } \\
\text { used), for example for unpacking and re-packing products. }\end{array}$ \\
\hline$C_{\text {RE-USE }}$ & Cost of Re-Use & [€/year] & $\begin{array}{l}\text { Cost of re-using packaging after the delivery of finished products to the } \\
\text { customer. It includes: } \\
C_{\text {REVEXT TRAN: the cost of transport for coming back to the company. It }} \\
\text { comprises the labour costs, depreciation of vehicles used (e.g. truck), cost } \\
\text { of the distance travelled; } \\
C_{\text {REVEXT ConD: the cost of conditioning packages to make them re-usable. It }} \\
\text { comprises the labour costs and depreciation of mechanical devices (if } \\
\text { used), for example for unpacking and re-packing products. }\end{array}$ \\
\hline$C_{\text {DISP }}$ & Cost of Disposal & {$[€ /$ piece $]$} & $\begin{array}{l}\text { Cost of disposing of damaged packages during the manufacturing stage. It } \\
\text { comprises the cost of disposal, the cost of transporting damaged packages } \\
\text { from the company to the landfill (labour costs, depreciation of vehicles } \\
\text { used (e.g. truck), cost of the distance travelled). }\end{array}$ \\
\hline
\end{tabular}




\begin{tabular}{cccc}
\hline Parameter & Nomenclatures & Units & Description \\
\hline$R_{\text {SUB }}$ & $\begin{array}{c}\text { Gain from Sub- } \\
\text { Product }\end{array}$ & {$[€ /$ piece $]$} & $\begin{array}{l}\text { The parameter identifies the possible gain obtained from the disposal of } \\
\text { damaged products. }\end{array}$ \\
\hline$R_{U D C}$ & $\begin{array}{c}\text { Gain from Direct } \\
\text { Sale of Pallet }\end{array}$ & {$[€ /$ piece $]$} & $\begin{array}{l}\text { This parameter identifies the possible gain obtained from the sale of } \\
\text { tertiary packaging to the final customer. }\end{array}$ \\
\hline
\end{tabular}

Table 4. Cost parameters of the model

Equation (1) introduces the general formula of the model.

$$
\begin{aligned}
& C_{T O T}=C_{E N G}+C_{O R D}+C_{P U R}+C_{R E N T}+C_{E X T T R A N}+C_{R E C}+
\end{aligned}
$$

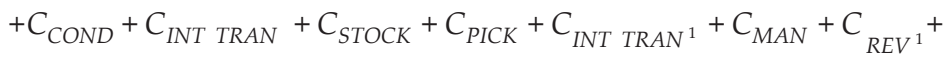

$$
\begin{aligned}
& +C_{\text {INTTRAN }{ }^{2}}+C_{\text {STOCK }^{1}}+C_{\text {PICK }}{ }^{1}+C_{\text {INT TRAN }}^{3}+C_{\text {REV }^{2}}+C_{\text {RE-USE }}+C_{\text {DISP }}-R_{\text {SUB }}-R_{\text {UDC }}
\end{aligned}
$$

Equation (2) presents the mathematical model, explaining each cost parameter in detail.

$$
\begin{aligned}
& C_{\text {TOT }}=\left(\sum_{i=1}^{4} \sum_{t=1}^{m} C_{E N G ~ i t}\right)+\left(N_{\text {ORD }} \cdot \sum_{i=1}^{4} \sum_{t=1}^{m} C_{\text {ORD it }}\right)+\left(\sum_{n=1}^{s} \sum_{i=1}^{4} \sum_{t=1}^{m} C_{P U R ~ n i t} \cdot\left(x_{n i t}+y_{n i t}\right)\right)+ \\
& +\left(\sum_{n=1}^{s} \sum_{i=1}^{4} \sum_{t=1}^{m} C_{R E N T ~ n i t} \cdot w_{n i t}\right)+\left(\sum_{n=1}^{s} \sum_{i=1}^{4} \sum_{t=1}^{m} C_{\text {EXT TRAN nit }} \cdot N_{\text {EXT TRAN nit }}\right)+ \\
& +\left(\sum_{i=1}^{4} \sum_{t=1}^{m} C_{R E C ~ i t}\right)+\left(\sum_{i=1}^{4} \sum_{t=1}^{m} C_{C O N D ~ i t}\right)+\left(\sum_{i=1}^{4} \sum_{t=1}^{m} C_{I N T \text { TRAN it }} \cdot N_{\text {INT TRAN it }}\right)+ \\
& +\left(\sum_{i=1}^{4} \sum_{t=1}^{m} C_{\text {STOCK } i t} \cdot\left(x_{i t}+y_{i t}+w_{i t}\right)\right)+\left(\sum_{i=1}^{4} \sum_{t=1}^{m} C_{\text {PICK it }} \cdot x_{i t}\right)+ \\
& +\left(\sum_{i=1}^{4} \sum_{t=1}^{m} C_{I N T \text { TRAN }{ }^{1} i t} \cdot N_{\text {INT TRAN }{ }^{1}{ }^{1} t}\right)+\left(\sum_{i=1}^{4} \sum_{t=1}^{m} C_{M A N i t} \cdot x_{i t}^{\prime}\right)+ \\
& +\left(\left(\sum_{i=1}^{4} \sum_{t=1}^{m} C_{R E V I N T \operatorname{TRAN}{ }^{1} i t} \cdot N_{R E V I N T \operatorname{TRAN}{ }^{1} i t}\right)+\left(\sum_{i=1}^{4} \sum_{t=1}^{m} C_{R E V I N T \operatorname{COND}{ }^{1} i t}\right)\right)+
\end{aligned}
$$

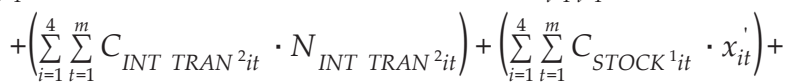

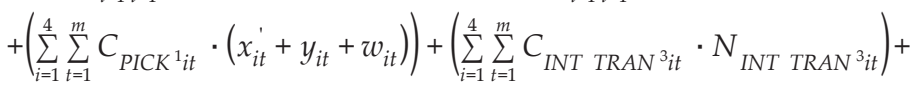

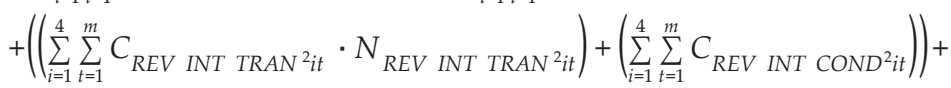

$$
\begin{aligned}
& +\left(\left(\sum_{r=1}^{q} \sum_{i=1}^{4} \sum_{t=1}^{m} C_{R E V \text { EXT TRAN rit }} \cdot N_{\text {REV EXT TRAN riit }}\right)+\left(\sum_{i=1}^{4} \sum_{t=1}^{m} C_{R E V \text { EXT COND it }}\right)\right)+ \\
& +\left(\sum_{i=1}^{4} \sum_{t=1}^{m} C_{\text {DISP it }}\right)-\left(\sum_{i=1}^{4} \sum_{t=1}^{m} R_{S U B ~ i t} \cdot r_{i t}\right)-\left(\sum_{r=1}^{q} \sum_{i=1}^{4} \sum_{t=1}^{m} R_{U D C \text { rit }} \cdot u_{r i t}\right)
\end{aligned}
$$

The mathematical model allows companies to have a complete tool for analysing the total packaging costs in order to understand packaging cost reductions and consequently the minimization of the impact of total packaging cost on total company cost. 


\section{E-commerce}

Among all operations, web operations are taking on an important role in the global trend of the purchasing process. During recent years, more and more people have begun to use the Internet and to buy a wide range of goods online. The World Wide Web (WWW) allows people to communicate simultaneously or asynchronously easily and effectively, shortening distance and time between individuals [40].

E-commerce is a new sales tool, in which consumers are able to participate in all the stages of a purchasing decision, while going through processes electronically rather than in a real shop. E-commerce is the process of trading goods, information, or services via computer networks including the Internet [41; 42]. There is an increasing consensus that e-commerce will represent a large share of retail markets in the future [43].

E-commerce channels in traditional companies have changed their operations and business strategy. That impact has been described by three main issues: integration, customization, and internationalization. First, e-commerce networks improve value chain integration by reducing transaction costs, facilitating JIT delivery, and improving information collection and processing [41; 42]. Secondly, e-commerce databases and direct links between producers and customers support high levels of product and service customization [44]. Finally, the Internet's international scope allows small companies to reach customers worldwide $[45 ; 46]$.

As the Internet becomes more popular, e-commerce promises to become a mainstay of modern business [47]. There are dozens of e-commerce applications such as home banking, shopping in online stores and malls, buying stocks, finding a job, conducting an auction and collaborating electronically on research and development projects [42].

According to Gunasekaran et al. [48], e-commerce supports functional activities in organization: marketing, purchasing, design production, sales and distribution, human resource management, warehousing and supplier development. For example, the advent of e-commerce has changed marketing practice [48]. E-commerce systems should provide sure access to use, overcoming differences in time to business, location, and language between suppliers and customers and at the same time support the entire trading process in Business to Business (B2B) e-commerce [49]. Communication and data collection constraints are reduced with web-based production of goods and services. Using database management, data warehouse, and data mining technologies, the web can facilitate interaction with customers and suppliers, data collection, and data analysis processes [50].

Table 5 [48] summarises e-commerce applications and e-commerce tools and systems to suggest how e-commerce might support functional activities.

The open standard of the Internet ensures that large organizations can easily extend their trading communities, by increasing the efficiency of their business operations. According to Gunasekaran et al. [48], Internet-based e-commerce enables companies to:

- Shorten procurement cycles through the use of online catalogues, ordering, and payment; 


\begin{tabular}{|c|c|c|}
\hline Functional areas & E-commerce applications & E-commerce tools and systems \\
\hline Marketing & $\begin{array}{l}\text { Product promotion, new sales channels, direct } \\
\text { savings, reduced cycle time, customer services. }\end{array}$ & $\begin{array}{l}\text { B2B e-commerce, Internet ordering, website } \\
\text { for the company. }\end{array}$ \\
\hline Purchasing & Ordering, fund transfer, supplier selection. & EDI, Internet-purchasing. \\
\hline Design & $\begin{array}{l}\text { Customer feedback, research on customer } \\
\text { requirements, product design, quality function } \\
\text { deployment, data mining and warehousing. }\end{array}$ & $\begin{array}{l}\text { WWW integrated CAD, Hyperlinks, 3D } \\
\text { navigation, Internet for data and information } \\
\text { exchange. }\end{array}$ \\
\hline Production & $\begin{array}{l}\text { Production planning and control, scheduling, } \\
\text { inventory management, quality control. }\end{array}$ & B2B e-commerce, MRP, ERP, SAP. \\
\hline Sales and distribution & $\begin{array}{l}\text { Internet sales, selection of distribution } \\
\text { channels, transportation, scheduling, third } \\
\text { party logistics. }\end{array}$ & $\begin{array}{l}\text { Electronic funds transfer, bar-coding system, } \\
\text { ERP, WWW integrated inventory management, } \\
\text { Internet delivery of products and services. }\end{array}$ \\
\hline $\begin{array}{l}\text { Human resource } \\
\text { management }\end{array}$ & $\begin{array}{l}\text { E-recruitment, benefit selection and } \\
\text { management, training and education using } \\
\text { WWW. }\end{array}$ & $\begin{array}{l}\text { E-mails, interactive web sites, WWW based } \\
\text { multimedia applications. }\end{array}$ \\
\hline Warehousing & $\begin{array}{l}\text { Inventory management, forecasting, } \\
\text { scheduling of work force. }\end{array}$ & EDI, WWW integrated inventory management. \\
\hline Supplier development & Partnership, supplier development. & $\begin{array}{l}\text { WWW assisted supplier selection, e-mails, } \\
\text { research on suppliers and products with WWW } \\
\text { and intelligent agents. }\end{array}$ \\
\hline
\end{tabular}

Table 5. E-commerce applications areas, tools and systems [48]

- Reduce development cycles and accelerate time-to-market through collaborative engineering, product, and process design;

- Gain access to worldwide markets at a fraction of traditional costs;

- Significantly increase the speed of communication, especially international communication;

- Drastically reduce purchasing and production cycles;

- Reduce the cost of communication that in turn can reduce inventory and purchasing costs;

- Promote a closer relationship with customers and suppliers;

- Provide a quick and easy way of exchanging information about a company and its products, both internally and outside the organization.

\section{Packaging and e-commerce in operations management}

Every year Internet-based companies ship millions of packages throughout the world [24].

Online shopping influences packaging and its interactions with industrial function, mainly with marketing. The more people shop online, the more the role and the function of packag- 
ing change, since the shelf presentation of the product becomes less important [24]. Visser [24] stated that it is difficult to translate the existing packaging design used for the traditional way of buying in a real shop and marketing tactics into online retailing. E-commerce requires a new paradigm for the entire product packaging system. For example, in real shop the traditional primary package is a good agent for any products, not only because of the text descriptions, but also for its visual communication. It can effectively deliver product information and brand identity, and is a good cognitive agent for recognition. In an online shop, users cannot directly see the package nor touch the product, but other characteristics such as protection and re-usability for efficient take-back of products take on great importance [40]. The direct feeling with customers is less important since the contact is mediated by the computer.

The Internet does not determine the design of packages. However, if online shopping is becoming more common, packaging design must be reconsidered [24]. The changing role of packaging in the purchase of a product makes it desirable and possible to give more attention to the consumer's perception of a brand while the user is using it, and less attention to its shelf presentation. Retailers that sell online have to consider packages as a means of marketing and disseminating information instead of a mere covering for a product [24].

Block and Segev [51] suggest the following e-commerce impacts on marketing:

- Product promotion: e-commerce enhances the promotion of products and services through direct information and interactive contact with customers;

- New sales channels: e-commerce creates a new distribution channel for existing products, owing to its direct support of research on customers and the bidirectional nature of communication;

- Direct savings: the cost of delivering information to customers by Internet results in substantial savings. Greater savings are also made in the direct delivery of digitized products compared to the costs of traditional delivery;

- Reduced cycle time: the delivery time for digitized products and services can be reduced. Also, the administrative work related to physical delivery, especially across international borders, can be reduced significantly;

- Customer service: it can be greatly enhanced for customers to find detailed information online. In addition, intelligent agents can answer standard e-mail questions in few seconds.

The advent of e-commerce has also had several implications on logistics and the environment. From the logistics point of view, packaging has to increase its function of protection and covering of products, since products have to be transported to reach the customer. The theme of reverse logistics takes on great importance since customers can return wrong and/or unsuitable products. The advent of Internet distribution produces significant savings in shipping, and can facilitate delivery. Even those who use transportations can use Internetbased tools to increase customer service. Web-based order tracking has become commonplace. It allows customers to trace the shipment of their orders without having to contact the 
shipper directly [48]. Several electronic tools, like Electronic Data Interchange (i.e. the structured transmission of data between organizations by electronic means, EDI) can have a significant impact on the management of online packaging. EDI enables minimal stocks to be held with the consequent saving in storage, insurance, warehousing and labour costs (reduction in manual processing reduces the need for people) [48]. The packaging system must ensure secure shipping, reduce the possibility of theft, increase security and identify where the products are in real time.

From the environmental point of view, packaging in e-commerce has very similar requirements to traditional shopping, such as the use of recyclable materials, reduction of the amount of materials used, possibility to re-use packages in case of returned products from customers, disposal of damaged packages with the minimum production of pollution.

Table 6 shows the main interactions between packaging and other industrial issues in both real and online shopping.

\begin{tabular}{ll}
\hline \multicolumn{1}{c}{ Real shop } & \multicolumn{1}{c}{ Online shop } \\
\hline Marketing: & Marketing: \\
Sell, differentiate, promote, value, & Brand identity, means of \\
inform, shelf presentation, visual & disseminating information, product \\
communication & promotion, \\
\hline Logistics: & Logistics: \\
Handle, transport, store, distribution & Protection and covering the products, \\
& transport, reverse logistics, security \\
\hline Environment: & Environment: \\
Reduction of materials used, re-use, & Reduction of materials, recyclable \\
recover, disposal & materials, re-use, disposal \\
\hline
\end{tabular}

Table 6. Packaging and industrial issues in real and online shops

\section{A case study: Packaging e-commerce logistics in operations management}

This section presents a case study on an Italian wholesaler; its main activities consist of purchasing goods from suppliers and selling and distributing them to retailers that in turn sell to end consumers through a "real shop".

The wholesaler is interested in starting a new business: the e-commerce activity. The wholesaler wants to sell directly to end consumers, bypassing the retailers and, at the same time, continue the B2B transactions.

Traditionally, the wholesaler receives goods from suppliers in the receiving area; the goods are unpacked, sorted and stored in the warehouse. When a retailer asks for products, they 
are picked from the shelves and packed according to the retailer's order. After that, the products packed in secondary packages are loaded onto the truck and dispatched to the retailer. Finally, he sells the products to end consumers in real shops. The packages are not labelled with identification technology (e.g. barcodes, RFID, etc.). Figure 13 shows in detail the activities of the wholesaler.

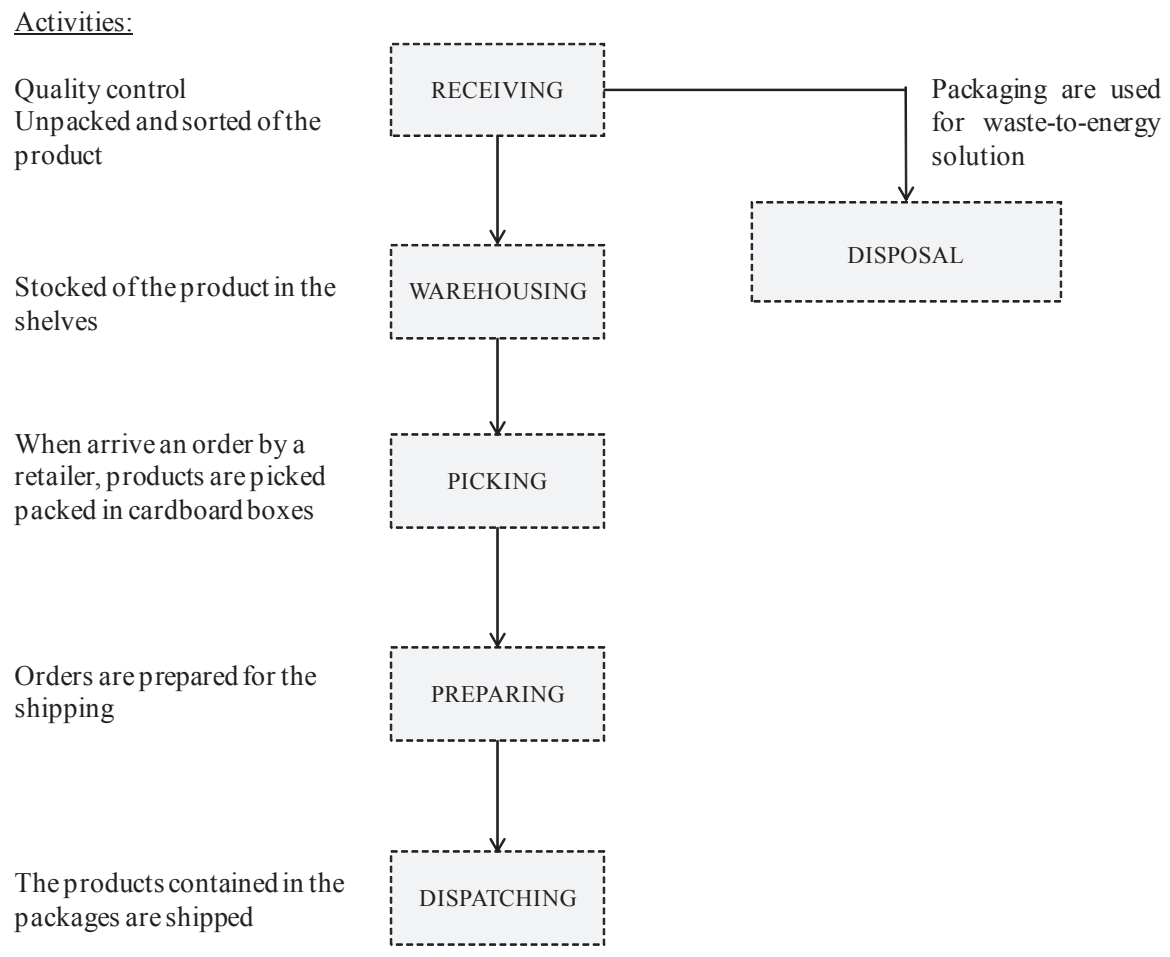

Figure 13. The wholesaler's activities

The project concerns the study of a new packaging system (in terms of material, shape, accessories used for protecting the product) to be used for online shopping. The new package has to take into account mainly the logistics aspects required by the e-commerce business.

The wholesaler has defined several requirements for the new packaging solution:

- Protection of the product: products contained in secondary packages have to be protected from mechanical shocks, vibrations, electrostatic discharge, compression, etc.;

- Handleability: the ergonomic aspect, that is everything relating to adaptations to the human physique and behaviour when using the product, has to be considered; the package has to be easy to open, easy to grip and user-friendly; 
- Security: packages must ensure secure shipping. It is necessary to install identification technologies, like RFID tags or barcodes, in secondary packages in order to reduce thefts, increase security, and reduce costs and time spent on the traceability of products;

- Respect for the environment: the package has to be recyclable, in line with the requirements of end consumers and has to have minimum environmental impact;

- Re-use of packages from the supplier when the products back to the wholesaler.

The research activity starts from the study of several typical orders defined by the wholesaler in order to determine the best packaging configurations that optimize the combination of logistics, protection of the product and re-use of packages. The wholesaler decided to re-use the cardboard boxes in which the products are sent by suppliers. This solution minimizes the packaging system costs and reduces the environmental impact. According to these considerations, Figure 14 shows an example of the secondary package chosen.

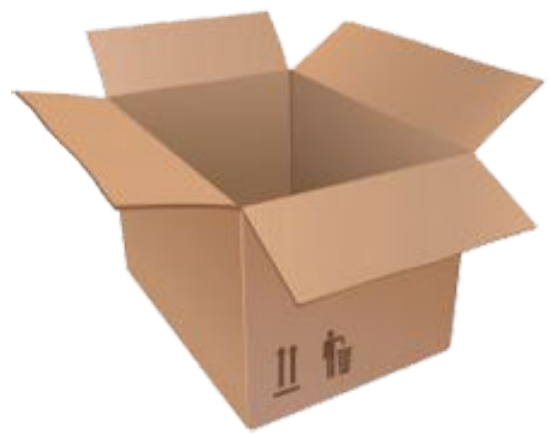

Figure 14. The typical cardboard box used as secondary package

After that, the accessories are chosen in order to protect products from mechanical shocks, vibrations and compression during transport. Pluriball, polystyrene and interior cushioning are chosen as flexible protective accessories (an example of interior cushioning is shown in Figure 15).

The authors have analysed the possibility to install RFID tags on secondary packages in order to find out the position of the products in real time and to increase security during transport, minimizing the possibility of thefts and loss of products. 


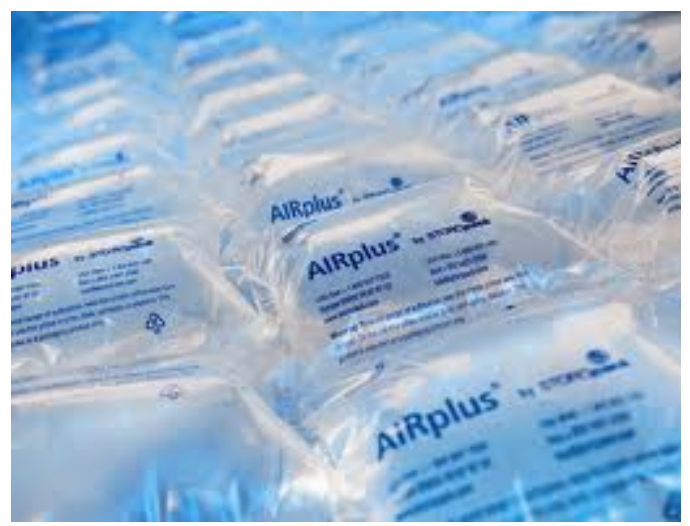

Figure 15. Accessories used for protecting products (courtesy of Soropack Group)

The new packaging solution presents several advantages in terms of:

- Protection of the product: the products inside the packages are protected thanks to the accessories used that increase the protection of products, damping the shocks during transport;

- Handleability: the package is user-friendly, easy to handle and to open;

- Security: the installation of RFID tags in the secondary packages allows the wholesaler to increase security during transport, reduce the number of thefts, and find out the position of the package at all times. This aspect may also be important for the end consumer since he can verify the position of the product he has ordered;

- Respect for the environment: the packages and accessories used for the e-commerce business can be recycled (the cardboard box is paper and the interior cushioning plastic) and secondary packages are re-used: the wholesaler use the cardboard with which the products arrive from the suppliers for dispatching products to end consumers.

In order to define a new packaging solution for the e-commerce business and, according to OM discipline, the strategic, tactical and operational levels have to be analysed. The definition of a new packaging solution for the e-commerce business, allowing transactions costs to be minimized and leading to an increase in business, is a strategic decision. The tactical management defines the main packaging requirements and the operational level has to implement the solution. The activities of the operational level are to test the products and packages in order to verify the resistance to shocks, build the website from sell by the WWW, study the shape, materials and accessories for packages, define a package that is as easy as possible to handle and transport and analyse the installation of RFID tags in secondary packages. Figure 16 shows in detail the decisions and operations at all levels in the pyramid of the OM decision levels. 


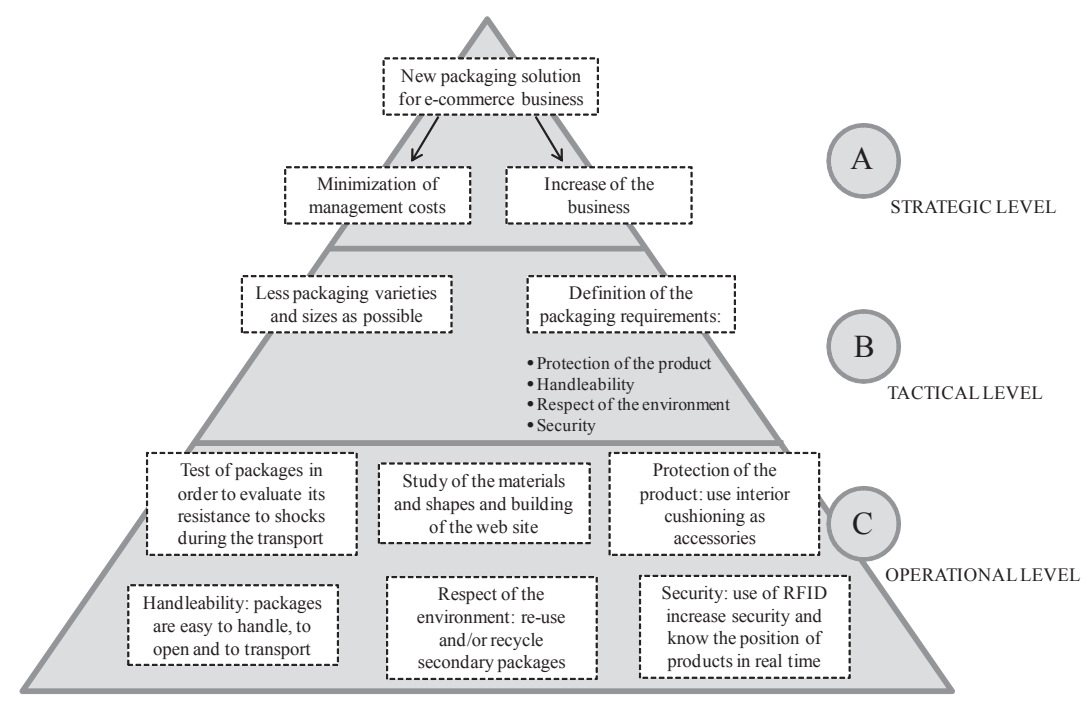

Figure 16. The pyramid of OM's decision levels for the case study

The new solution is implemented by the wholesaler and implies several benefits: an increase in sales with minimum effort, a reduction in transaction costs and an increase in customer satisfaction thanks to the environmentally friendly packaging. Moreover, the products are now traced every time and in real time, thanks to the installation of RFID tags in secondary packages, reducing thefts, loss and increasing security.

\section{Conclusion}

Operations Management is defined as the management function responsible for all activities directly concerned with making a product, collecting various inputs and converting them into desired outputs through operations [5]; OM discipline can be applied to manufacturing, service industries and non-profit organizations.

Over the years, new tools and elements such as TQM, JIT, and ECR have become part of the OM discipline that recognizes the need to integrate these tools and elements of the management system with the company's strategy. In order to manage all operations, organizations have to define a strategy, whose decisions are based on three levels: strategic, tactical and operational. Each level is integrated with the others and has to be interrelated in order to follow a common purpose. Strategic, tactical and operational decision levels are strictly connected with packaging features.

Packaging is a multidimensional function that takes on a fundamental role in organizations to achieve successful management of operations. Johansson [26] stated that the packaging system (made up of primary, secondary and tertiary packaging and accessories used to pro- 
tect the products inside) could be divided into three main functions that interact with each other. They are flow, market and environment. The flow function consists of packaging features that contribute to more efficient handling during transport. The market function considers the aesthetics aspect in order to create value for the product and finally, the environment function has the purpose of reducing the negative effects of packaging on the environment. Packaging has an important role along the whole supply chain: all the parties (e.g. suppliers, manufacturers, retailers, end consumers) are interested in the packaging features (e.g. protection of the product, aesthetics aspects, reduction of the environmental impact, etc.).

In order to find the optimal packaging system management, the authors have developed a complete mathematical model that represents added value for companies seeking to estimate the total costs of their packaging system and consequently its impact on total company costs. The model considers all the cost parameters regarding the packaging system, e.g. engineering cost, warehousing cost, labour cost, transport cost, etc.

The packaging system takes on a fundamental role in online shopping. In recent years, web operations have evolved and organizations who want to start online business have to reconsider the role of packaging: from merely "shop window" in real shops, packaging has to transform into a means of information and transport. The changing role of packaging in the purchase of a product makes it desirable and possible to give more attention to the consumer's perception of a brand while he is using it, and less attention to its shelf presentation [24].

The correlation between packaging and e-commerce is a relatively new aspect. The case study described in Section 5 has shown the will of organizations to enter into the new ecommerce business, but also the changes that they have to make to the packaging system, since the packaging requirements of online shopping are different from those of a real shop. Organizations gain important benefits from e-commerce, such as the increase in labour cost savings.

Several modifications have to be considered for future thinking concerning online packaging. Communicative and information functions must be built in to help consumers to identify the products easily and to assist them in making precise decisions and reinforcing brand identity for consumers online. In addition, the ability to attract consumers' attention and incite their curiosity about the products are important points to analyse in the future in order to increase the potential development of packages for online shopping.

\section{Author details}

Alberto Regattieri ${ }^{1}$ and Giulia Santarelli ${ }^{2}$

1 DIN - Department of Industrial Engineering, University of Bologna, Bologna, Italy

2 DTG - Department of Management and Engineering, University of Padova, Padova, Italy 


\section{References}

[1] Waters D. Operations management - Producing goods and services. Addison-Wesley (eds.). Great Britain; 1996.

[2] Regattieri A., Olsson A., Santarelli G., Manzini R. An empirical survey on packaging perception for Italian companies and a comparison with Swedish situation. Proceedings of the $24^{\text {th }}$ NOFOMA Conference, June 2012, Turku, Finland.

[3] Regattieri A., Santarelli G. and Olsson A. The Customers' Perception of Primary Packaging: a Comparison between Italian and Swedish Situations. Proceedings of the $18^{\text {th }}$ IAPRI World Packaging Conference, June 2012, San Luis Obispo, California.

[4] Drejer A., Blackmon K., Voss C. Worlds apart? - A look at the operations management area in the US, UK and Scandinavia. Scandinavian Journal of Management 2000; 16 45-66.

[5] Waller D.L. Operations management: a supply chain approach. $2^{\text {nd }}$ edition. Thompson (ed.). London; 2003.

[6] Schmenner R.W., Swink M.L. On theory in operations management. Journal of Operations Management 1998; 17 97-113.

[7] Kleindorfer P.R., Van Wassenhove L.N. Strategies for building successful global businesses. In: Gatignon and Kimberley (eds.) Managing risk in global supply chains. 2004. p288-305.

[8] Hayes R.H., Wheelwright S.C. Restoring out competitive edge: competing through manufacturing. In:Wiley, New York; 1984.

[9] Hammer M. Re-engineering work: don't automate, obliterate. Harvard Business Review 1990; 68(4) 104-112.

[10] Hammer M., Champy J. Reengineering the corporation: a manifesto for business revolution. National Bestseller, 1993.

[11] Ahire S.L. Total Quality Management interfaces: an integrative framework. Management Science 1997; 27(6) 91-105.

[12] Sugimori Y., Kusunoki F., Cho F., Uchikawa S. Toyota production system and kanban system: materialization of just-in-time and respect for human systems. International Journal of Production Research 1977; 15(6) 553-564.

[13] Hamel G., Prahalad C.K. Competing for the future: break-through strategies for sizing control of your industry and creating the markets of tomorrow. Harvard Business School Press (ed.). Boston, Massachussetts; 1994.

[14] Skinner W.S. Manufacturing strategy on the "S" curve. Production and Operations Management 1996; 5(1) 3-14. 
[15] Coyle J.J., Bardi E.J., Langley C.J. Jr. The management of business logistics. West publishing company, St Paul, MN, 1996.

[16] Shaw R. Computer aided marketing \& selling. In:Butterworth Heinemann; 1991.

[17] Womack J.P., Jones D.T. Lean consumption. Harvard Business Review 2005; 83(3) 58-68.

[18] Hansson E., Olsson M. Ellos: a case study in operations management and packaging logistics. School of economics and commercial low, Göteborg University, Sweden; 2000.

[19] Hellström D., Saghir M. Packaging and logistics interactions in retail supply chains. Packaging Technology and Science 2006; 20(3) 197-216.

[20] Underwood R.L. The communicative power of product packaging: creating brand identity via lived and mediated experience. Journal of Marketing Theory and Practice 2003; 11(1) 61-65.

[21] Silversson J., Jonson G. Handling time and the influence of packaging design. Licentiate Thesis Lund University, Sweden; 1998.

[22] Saghir M. Packaging logistics evaluation in the Swedish retail supply chain. PhD Thesis, Lund University, Sweden; 2002.

[23] Long D.Y. Commercial packaging design. In: Yellow Lemon. 1982, Taipei, Taiwan.

[24] Visser E. Packaging on the web: an underused resource. Design Management Journal 2002; 62-67.

[25] Twede D. The process of packaging logistical innovation. Journal of Business Logistics 1992; 13(1) 69-94.

[26] Johansson K., Lorenszon-Karlsson A., Olsmats C., Tiliander L. Packaging logistics. Packforsk, Kista; 1997.

[27] Chan F.T.S., Chan H.K., Choy K.L. A systematic approach to manufacturing packaging logistics. The International Journal of Advanced Manufacturing Technology 2006; $29(9 ; 10)$ 1088-1101.

[28] Verruccio M., Cozzolino A., Michelini L. An exploratory study of marketing, logistics, and ethics in packaging innovation. European Journal of Innovation Management 2010; 13(3) 333-354.

[29] Olsson A., Larsson A.C. Value creation in PSS design through product and packaging innovation processes. In Sakao and Lindahl (eds.) Introduction to product/service-system design; 2009. p93-108.

[30] Nilsson F., Olsson, A., Wikström F. Toward sustainable goods flows - a framework from a packaging perspective. Proceedings of $23^{\text {rd }}$ NOFOMA Conference, June 2001, Norway. 
[31] Sonneveld K., James K., Fitzpatrick L., Lewis H. Sustainable packaging, how we define and measure it? 22 ${ }^{\text {nd }}$ IAPRI symposium of packaging; 2005.

[32] Svanes E. Vold M., Møller H., Kvalvåg Pettersen M., Larsen H., Hanssen O.J. Sustainable packaging design: a holistic methodology for packaging design. Packaging Technology and Science 2010; 23(2) 161-175.

[33] Pilditch J. The silent salesman. $2^{\text {nd }}$ ed. In: Doble \& Brendon (eds.). 1973, Plymouth.

[34] Bramklev C. A survey on the integration of product and package development. International Journal Manufacturing Technology and Management 2010; 19(3;4) 258-278.

[35] Bjärnemo R., Jönson G., Johnsson M. Packaging logistics in product development. In Singh J., Lew S.C. \& Gay R. (eds.). Proceedings of the $5^{\text {th }}$ International Conference: computer integrated manufacturing technologies for new millennium manufacturing, 2000, Singapore.

[36] Helander F. Svensk Förpacknignsindustri. Var är vi idag och vad påverkar utvecklingen framåt? Packbridge publication, Malmö, Sweden. 2010.

[37] Kano N., Seraku N., Takahashi F., Tsjui F. Attractive quality and must-be-quality. Hinshitsu 1984; 2 147-156.

[38] Löfgren M., Witell L. Kano's theory of attractive quality and packaging. The Quality Management Journal 2005; 12(3) 7-20.

[39] Berger C., Blauth R., Boger D., Bolster C., Burchill G., DuMouchel W., Poulist F., Richter R., Rubinoff A., Shen D., Timko M., Walden D. Kano's methods for understanding customer-defined quality. The Center of Quality Management Journal 1993; 2(4).

[40] Huang K.L., Rust C., Press M. Packaging design for e-commerce: identifying new challenges and opportunities for online packaging. College of Digital Design. Visual Communication Design Graduate School of Digital Content and Animation, 2009.

[41] Fraser J., Fraser N., McDonald F. The strategic challenge of electronic commerce. Supply Chain Management: An International Journal 2000; 5(1) 7-14.

[42] Turban E., Lee J., King D. and Chung H.M. Electronic commerce: a managerial perspective. Prentice-Hall International (UK) Limited, London, 2000.

[43] Giovani J.C. Towards a framework for operations management in e-commerce. International Journal of Operations \& Production Management 2003; 23(2) 200-212.

[44] Skjoett-Larsen T. European logistics beyond 2000. International Journal of Physical Distribution \& Logistics Management 2000; 30(5) 377-387.

[45] Soliman F., Youssef M. The impact of some recent developments in e-business in the management of next generation manufacturing. International Journal of Operations \& Production Management 2001; 21(5;6) 538-564. 
[46] Zugelder M.T. Flaherty T.B. and Johnson J.P. Legal issues associated with international internet marketing. International Marketing Review 2000; 17(3) 253-271.

[47] Altmiller J.C., Nudge B.S. The future of electronic commerce law: proposed changes to the uniform commercial code. IEEE Communication Magazine 1998; 36(2) 20-22.

[48] Gunasekaran A., Marri H.B., McGaughey R.E., Nebhwani M.D. E-commerce and its impact on operations management. International Journal of Production Economics 2002; 75 185-197.

[49] Boll S., Gruner A., Haaf A., Klas W. EMP - A database-driven electronic market place for business-to-business commerce on the internet. Distributed and Parallel Database 1999; 7(2) 149-177.

[50] Wang F., Head M., Archer N. A relationship-building model for the web retail marketplace. Internet Research 2000; 10(5) 374-384.

[51] Block M., Segev A. Leveraging electronic commerce for competitive advantage: a business value framework. Proceedings of the Ninth International Conference on EDI-ISO. 1996, Bled, Slovenia. 
